\title{
COMPORTAMENTO DO COBRE APLICADO NO SOLO POR CALDA BORDALESA
}

\section{FABIANA FERREIRA FELIX}

Dissertação apresentada à Escola Superior de Agricultura "Luiz de Queiroz", Universidade de São Paulo, para obtenção do título de Mestre em Agronomia, Área de Concentração: Solos e Nutrição de Plantas.

P I R A C I C A B A

Estado de São Paulo - Brasil

Maio - 2005 


\title{
COMPORTAMENTO DO COBRE APLICADO NO SOLO POR CALDA BORDALESA
}

\author{
FABIANA FERREIRA FELIX
}

Engenheira Agrônoma

Orientador: Prof. Dr. ARNALDO ANTÔNIO RODELLA

\begin{abstract}
Dissertação apresentada à Escola Superior de Agricultura "Luiz de Queiroz", Universidade de São Paulo, para obtenção do título de Mestre em Agronomia, Área de Concentração: Solos e Nutrição de Plantas.
\end{abstract}

P I R A C I C A B A

Estado de São Paulo - Brasil

Maio - 2005 
Dados Internacionais de Catalogação na Publicação (CIP) DIVISÃO DE BIBLIOTECA E DOCUMENTAÇÃO - ESALQ/USP

Felix, Fabiana Ferreira

Comportamento do cobre aplicado no solo por calda bordalesa / Fabiana Ferreira Felix. - - Piracicaba, 2005.

74 p. : il.

Dissertação (mestrado) - - Escola Superior de Agricultura Luiz de Queiroz, 2005.

Bibliografia.

1. Calda bordalesa 2. Cobre 3. Fruticultura 4. Química do solo I. Título

CDD 631.41

"Permitida a cópia total ou parcial deste documento, desde que citada a fonte - $\mathrm{O}$ autor" 


\section{DEDICATÓRIA}

A Deus.

A meus queridos pais Francisco e Carolina, Pelo amor, carinho e compreensão.

\section{OFEREÇO}

A Fernando por fazer parte de minha vida e pelas horas gastas ao meu lado;

A Aparecido pela paciência.

A Dalva por ser uma grande mãe para mim e para minha filha;

A todos que me incentivaram antes e durante a concretização deste projeto de vida.

A Eduarda, minha filha e meu maior projeto. 


\section{AGRADECIMENTOS}

Ao Prof. Dr. Arnaldo Antonio Rodella pela orientação, amizade e paciência.

A Escola Superior de Agricultura "Luiz de Queiroz”, ao Departamento de Solos e Nutrição de Plantas e à Coordenação do Programa de Pós-graduação do departamento pela oportunidade.

Ao Conselho Nacional de Pesquisa (CNPq) pela concessão da bolsa de estudos.

Aos Professores Álvaro Pires da Silva, Luis Reynaldo F. Alleoni e Arquimedes Lavorenti pelos equipamentos, e infra-estrutura disponibilizados no decorrer da pesquisa.

Em especial, a Bibliotecária Eliana Garcia, pela grade ajuda nas correções.

Aos funcionários do Departamento de Solos e Nutrição de Plantas, em especial ao Luís Silva, Nancy, Flávia e Jaqueline.

Aos funcionários da Química Ambiental: Rita e Ana pela paciência, ajuda e amizade, Lenita, Janaina, Angélica, Armelinda, Gertrudes e Vanessa.

Ao Eng. Agrônomo Ivan José Ribeiro Antunes e ao técnico Antônio Marcos Luize do Centro Avançado de Pesquisa Tecnológica do Agronegócio de Frutas pelas amostras de solo.

Aos amigos pós-graduandos, em especial a Lucia, Lílian, pela amizade sincera e por tudo o quanto me ajudaram. Aos colegas: Karina, Susian, Virginia, Letícia, Estevão, Gláucia, Cristiano e Jonas pelos momentos de descontração e amizade.

Aos estagiários Claudeir (51), Felipe, e minha amiga Carol.

A Márcia que fez o papel de irmã, mãe, conselheira e amiga e a meu grande amigo Mauricio.

E a todos aqueles que direta ou indiretamente ajudaram na conclusão deste trabalho.

"Cada um sabe a alegria e a dor que traz no coração"

João Ubaldo Viera 


\section{SUMÁRIO}

Página

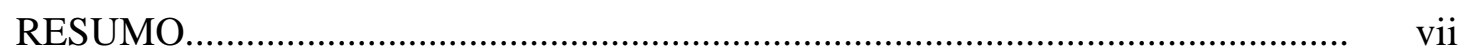

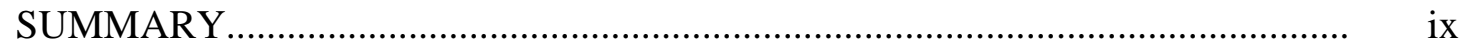

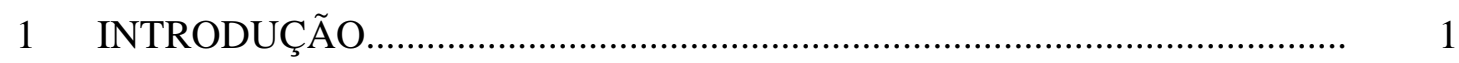

2 REVISÃO DE LITERATURA.................................................................... 3

$2.1 \quad$ Potencialidades da fruticultura no Estado de São Paulo................................. 3

2.1.1 A cultura da uva.......................................................................................... 4

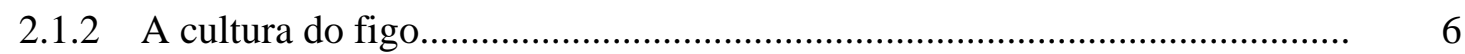

2.2 Uso de calda bordalesa em frutíferas e conseqüências.................................... 8

$2.3 \quad$ Comportamento do cobre no solo................................................................. 11

2.3.1 Método de Neubauer.................................................................................... 17

2.3.2 Relações entre alguns materiais e compostos orgânicos e o comportamento de metais no solo..................................................................................... 18

2.3.2.1 Sistema Ácido Cítrico/Citrato.......................................................................... 18

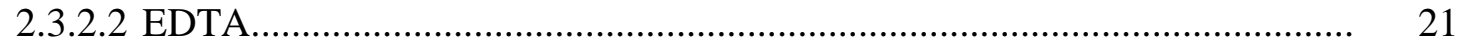

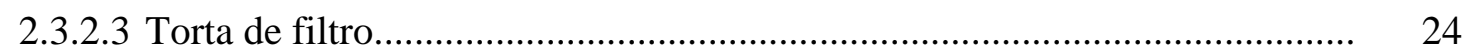

2.3.2.4 Esterco de Galinha.......................................................................................... $\quad 25$

3 MATERIAL E MÉTODOS.......................................................................... 28

3.1 Mobilização do cobre aplicado pela calda bordalesa em colunas de solo..... 28

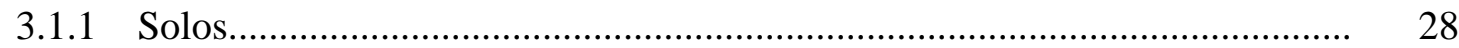

3.1.2 Montagem das colunas................................................................................. 29 
3.1.3 Aplicação dos tratamentos.............................................................................. 31

3.1.4 Coleta dos lixiviados.............................................................................. 32

3.1.5 Análise do solo contido nas colunas.............................................................. 33

3.2. Comportamento do cobre em alguns solos cultivados com frutíferas tratados com calda bordalesa...................................................................... 34

3.2.1 Análises de solo.......................................................................................... 35

3.2.2 Fracionamento do cobre............................................................................ 36

3.3. Avaliação da disponibilidade do cobre pelo Método de Neubauer

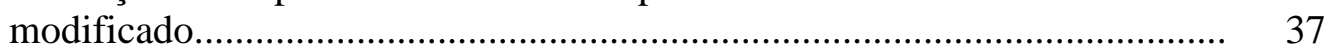

3.4. Análise estatística..................................................................................... $\quad 38$

$4 \quad$ RESULTADOS E DISCUSSÃO.................................................................... 39

4.1 Mobilização do cobre aplicado pela calda bordalesa em colunas de solo...... 39

4.1.1 Análise dos lixiviados.............................................................................. 39

4.1.2 Análise do solo das colunas de lixiviação......................................................... 44

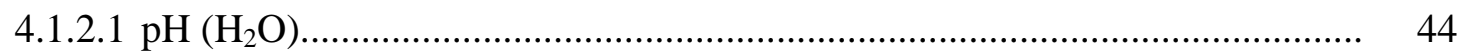

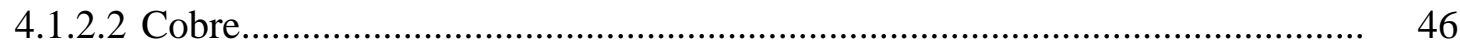

4.2 Avaliação da disponibilidade do cobre pelo Método de Neubauer................. 48

4.2.1 Solos do experimento em coluna..................................................................... 49

4.2.2 Solos coletados em áreas de frutíferas sob aplicação de calda bordalesa........ 50

4.3 Comportamento do cobre em solos cultivados com frutíferas tratados com calda bordalesa......................................................................................... 53

4.3.1 Teores de Cu total do solo.......................................................................... 53

4.3.2 Teor cobre disponível do solo pelo DTPA...................................................... 55

4.3.3 Fracionamento do cobre em amostras de solos de pomares de figo e uva....... 58

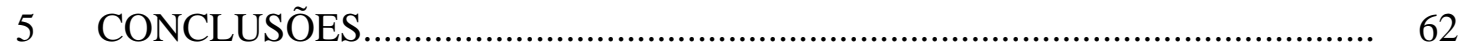

REFERÊNCIAS BIBLIOGRÁFICAS........................................................... 63 


\title{
COMPORTAMENTO DO COBRE APLICADO NO SOLO POR CALDA BORDALESA
}

\author{
Autora: FABIANA FERREIRA FELIX
}

Orientador: Prof. ARNALDO ANTÔNIO RODELLA

\section{RESUMO}

Apesar da preocupação atual com a contaminação do ambiente, pelo uso agrícola de resíduos industriais e urbanos, metais pesados podem ser incorporados ao solo por práticas agrícolas tradicionais como uso de fertilizantes e defensivos. Objetivando avaliar o comportamento do cobre aplicado ao solo através de calda bordalesa foram conduzidos ensaios nos quais o fungicida foi aplicado ao solo acondicionado em colunas, bem como consideradas amostras de solo sob cultura de frutíferas. A mobilização do Cu foi estudada em experimento com colunas de lixiviação, feitas de tubos de cloreto de polivinil (PVC), utilizando dois tipos de solos: Latossolo Vermelho eutroférrico (LVef) e Latossolo Vermelho Amarelo distrófico típico (LVAd). O cobre aplicado por um material alcalino como a calda bordalesa é relativamente imóvel no solo, mas pressupõe-se que poderá ser mobilizado pela ação de compostos orgânicos que atuam como complexantes. Desta forma, foram aplicados como compostos orgânicos: dois materiais de uso generalizado na agricultura (esterco de galinha e torta de filtro); um material sintético de elevado poder complexante ( $\left.\mathrm{NaH}_{2} \mathrm{EDTA}\right)$ e citrato de amônio para representar os agentes quelantes de ocorrência natural no ambiente. Em adição ao experimento em colunas, para determinar as frações de cobre presente no solo, foram coletadas amostras de solo na profundidade de 0-20 
cm, no município de Louveira, Estado de São Paulo, em pomares de frutíferas onde se usa rotineiramente calda bordalesa como fungicida. Nesses locais, o teor de $\mathrm{Cu}$ do solo extraído por DTPA variou entre 6,5-34,3 mg Cu kg${ }^{-1}$, enquanto que o teor de $\mathrm{Cu}$ total variou entre 40,8-108,8 $\mathrm{mg} \mathrm{kg}^{-1}$. Para avaliar a disponibilidade do $\mathrm{Cu}$ nos solos de Louveira e nos solos do experimento em colunas foi escolhido o método de Neubauer, pela vantagem de ser um método biológico de determinação da quantidade disponível de elementos no solo. A lixiviação na coluna do solo LVAd, onde foi aplicado o EDTA, conseguiu mobilizar 436,5 $\mu \mathrm{g}$ de $\mathrm{Cu}$, massa que representa uma fração muito pequena do cobre total aplicado ao solo por meio da calda bordalesa. Trata-se, entretanto, de um valor bastante significativo frente ao que foi removido nos demais tratamentos. Embora quase não tenha sido mobilizado cobre para fora das colunas, os resultados da análise química do solo indicaram a movimentação do cobre dos segmentos superiores para os inferiores, sob a ação dos tratamentos, na faixa de 5,0-48,2 mg Cu. Quanto à absorção de cobre pelas plantas no experimento de Neubauer, observou-se que a aplicação do EDTA favoreceu a absorção do cobre pelas plantas de arroz em ambos os solos estudados, entretanto não influenciou na massa seca das plantas. Já nas amostras dos solos de Louveira a absorção de cobre diminuiu a massa seca das plantas, tanto quando se considerou a concentração de cobre no tecido vegetal como a massa total de cobre absorvido. O Cu absorvido pelas plantas também se correlacionou com teores de cobre trocável, cobre ligado a carbonato e cobre ligado a óxidos de Fe e Mn, obtidos no estudo de fracionamento. O extrator DTPA mostrou ainda ser um bom indicador da disponibilidade de cobre aplicado pela calda bordalesa. 


\section{BEHAVIOR OF COPPER APPLIED TO SOIL THROUGH BORDEAUX MIXTURE}

Author: FABIANA FERREIRA FELIX

Adviser: Prof. ARNALDO ANTÔNIO RODELLA

\section{SUMMARY}

Despite the current concerns regarding the environment contamination by the agricultural use of industrial and urban wastes, heavy metals can be incorporated to the soil through traditional fertilizers and defensives. Aiming to evaluate the behavior of copper applied to the soil through the Bordeaux mixture, trials were carried out in which the fungicide was applied to the soil packed in columns, as well as samples of soil under fruit cultures were considered. The mobilization of $\mathrm{Cu}$ was studied in experiments with leaching columns, which consisted of polyvinyl chloride tubes (PVC), using two types of soil: Latossolo Vermelho eutroférrico (LVef) e Latossolo Vermelho Amarelo distrófico típico (LVAd). Copper applied through an alkaline material such as the Bordeaux mixture is relatively immobile in the soil but it is expected to be mobilized by the action of organic complexing compounds. This way they were applied as organic compounds, two materials generally used in agriculture: poultry manure and filter cake; a synthetic material with high affinity for metals $\left(\mathrm{NaH}_{2} \mathrm{EDTA}\right)$ and ammonium citrate in order to represent the ligants of wide spread occurrence in the environment. In addition to the experiment in columns and to determine the fractions of copper present in the soil, 0-20 cm samples of soil were collected in grape and fig orchard located in the city of Louveira , SP, where the Bourdeaux mixture is commonly used as a fungicide. Is these places the total copper content of the soil extracted by DTPA varied between 40,8-108,8 $\mathrm{mg} \mathrm{kg}^{-1}$. To evaluate the availability of copper in the soil of Louveira, and in the soils of 
the column experiment, the Neubauer method was chosen due to the advantage of being a biological method of determination of the available amount of elements in the soil. The leaching in the LVAd soil column, where EDTA was applied was able to mobilize 436,5 $\mu \mathrm{g}$ of $\mathrm{cu}$, mass that represents a very small fraction of the total copper applied to the soil through the Bordeaux mixture. It refers to, subconsequently to a very significant amount when compared to the quantity obtained through other methods. Although almost no copper was removed out of the columns, the results of the chemical analysis indicated the movement of copper from the upper segments to the lower segments, under the action of treatments, the range of 5-48,2 $\mathrm{mg}$ of copper. Regarding the absorption of copper by plants in the Neubauer experiment it was observed that the application of EDTA favored the absorption of copper by the rice plants, in both studied soil, however it didn't influence the dry mass of plants. In the soil samples from Louvreira, the copper absorption diminished the total dry mass of the plants, when considered the copper concentration in the vegetal tissue, as well as the total content of copper absorbed. The copper absorbed by the plants was correlated to exchangeable copper content as well as copper linked to carbonate and copper linked to oxides of Fe and Mn, obtained through the fractioning study. The DTPA extractor proved to be a good indicator of the availability to plants of copper applied through the Bordeaux mixture. 


\section{INTRODUÇÃO}

A introdução de metais pesados no solo pode ser efetuada através de diferentes meios, sendo bastante estudadas as aplicações de biossólidos e de resíduos industriais. Entretanto, práticas agrícolas tradicionais também podem contribuir para levar metais ao solo, através do uso de fertilizantes minerais, defensivos e mesmo adubos orgânicos, como esterco de suínos.

Dentre os fungicidas tradicionais utilizados na agricultura destaca-se a calda bordalesa. Embora seja um fungicida de uso relativamente antigo, é considerado ainda um dos produtos mais eficientes no combate de parasitas das plantas e doenças como: mal de Sigatoka em bananeira; antracnose em mamão, manga, uva; entomosporiose em marmelo; ferrugem em araçá, figo, jabuticaba, goiaba, pêssego; gomose em plantas diversas; melanose em laranja; verrugose em laranja, abacate e sarna em ameixa, maçã, pêra e pêssego.

O uso da calda bordalesa tem sido permitido na agricultura orgânica porque, segundo seus defensores, "o sulfato de cobre é um produto pouco tóxico que contribui para melhorar o equilíbrio nutricional das plantas”. Deste modo, o produto que parecia fadado a ser substituído por fungicidas mais modernos, voltou a ser usado devido à expansão da agricultura orgânica. Entretanto, muitos estudos alertam que o uso intensivo de calda bordalesa em vinhedos da Europa por mais de 100 anos para combate de míldio causou aumentos significativos de cobre na camada superficial dos solos.

Com o transcorrer dos anos, sucessivas aplicações de calda bordalesa em solos de regiões tropicais podem elevar o teor de cobre do solo a níveis preocupantes. É de interesse, portanto, avaliar o destino e o comportamento no solo do cobre proveniente desse fungicida tradicional. 
Qualquer abordagem sobre o comportamento de metais no solo requer necessariamente o conhecimento das formas sob as quais os mesmos ocorrem. Pode-se determinar a proporção do metal em diferentes frações da fase sólida, através do procedimento denominado fracionamento ou extração seqüencial. Por outro lado, avaliações de biodisponibilidade, sejam através de soluções extratoras ou por meio de experimentos com plantas são também freqüentemente empregados no estudo de metais no solo.

Nesse contexto, os principais objetivos do presente estudo são:

- avaliar em condições de laboratório, a ação de torta de Filtro e esterco de Galinha, bem como dos compostos orgânicos $\mathrm{NaH}_{2}$ EDTA e citrato de amônio, na mobilização do cobre aplicado por calda bordalesa em colunas de solo;

- avaliar o teor total e o teor disponível de cobre em algumas áreas sob cultivo de frutíferas no Estado de São Paulo, bem como sua distribuição entre as frações da fase sólida do solo;

- estudar a biodisponibilidade do $\mathrm{Cu}$ em solos tratados com calda bordalesa, usando o método de Neubauer modificado;

As hipóteses a serem testadas são:

- o cobre aplicado por um material alcalino é relativamente imóvel no solo, mas pode ser mobilizado pela ação de compostos orgânicos que atuam como complexantes.

- o cobre total se apresenta em teores elevados em solos tradicionalmente cultivados com frutíferas no Estado de São Paulo, que recebem aplicações freqüentes de calda bordalesa. 


\section{REVISÃO DE LITERATURA}

\subsection{Potencialidades da fruticultura no Estado de São Paulo}

Em 2004, o Brasil foi o terceiro produtor mundial de frutas alcançando uma produção de 38 milhões de toneladas, perdendo apenas para China e Índia. No mesmo ano, as exportações brasileiras de frutas frescas movimentaram cerca de US\$ 370 milhões, com aumento de $10 \%$ em relação ao ano anterior. Os principais destinos do produto brasileiro são os países europeus, as Américas do Norte e do Sul e o Oriente Médio, além de perspectivas de vendas para o mercado asiático (Revista Globo Rural, 2005).

O Estado de São Paulo é responsável pela maior parte da produção nacional de frutas (um terço do total), sendo considerado o maior produtor de frutas frescas do Brasil. O estado detém 77\% da produção de laranja, 17\% da produção de banana, 36\% da produção de manga, $46 \%$ da produção de melancia, 45\% da produção de abacate e 31\% da produção de goiaba. Considerando-se a média de um emprego por hectare, a fruticultura gera no Estado de São Paulo cerca de um milhão de empregos só na produção (Gutierrez, 2000).

Dentre os produtos de relevante importância no âmbito da fruticultura, São Paulo destaca-se também pela sua produção de uva e figo. O estado é o segundo maior produtor de uva e de figo do Brasil perdendo apenas para o Rio Grande do Sul. 


\subsubsection{A cultura da uva}

A uva é produzida hoje em praticamente todas as regiões do Brasil. Tem grande importância econômica no sul do país. Em todas as regiões de produção existem cultivares nobres de mesa e também de vinhos considerados de boa qualidade. No Brasil, o maior estado produtor de uva, Rio Grande do Sul representa 46\% da produção total brasileira, seguindo-se São Paulo com 21\%, Pernambuco e Paraná com 10 \% cada um, Bahia com 8\% e outros estados com apenas 5\% (IBGE, 2003).

A videira é cultivada comercialmente no Brasil desde o período colonial. No começo do século XX ocorreu a exploração da Niágara Branca para uva de mesa, variedade rústica e proveniente dos Estados Unidos. Em 1933, no município de Jundiaí, SP, em conseqüência de mutação somática em uma planta de Niágara Branca, surgiu a variedade Niágara Rosada, que transformou toda a estrutura vitícola do Estado de São Paulo, tornando-o maior produtor de uvas de mesa do Brasil (Pommer et al., 1997).

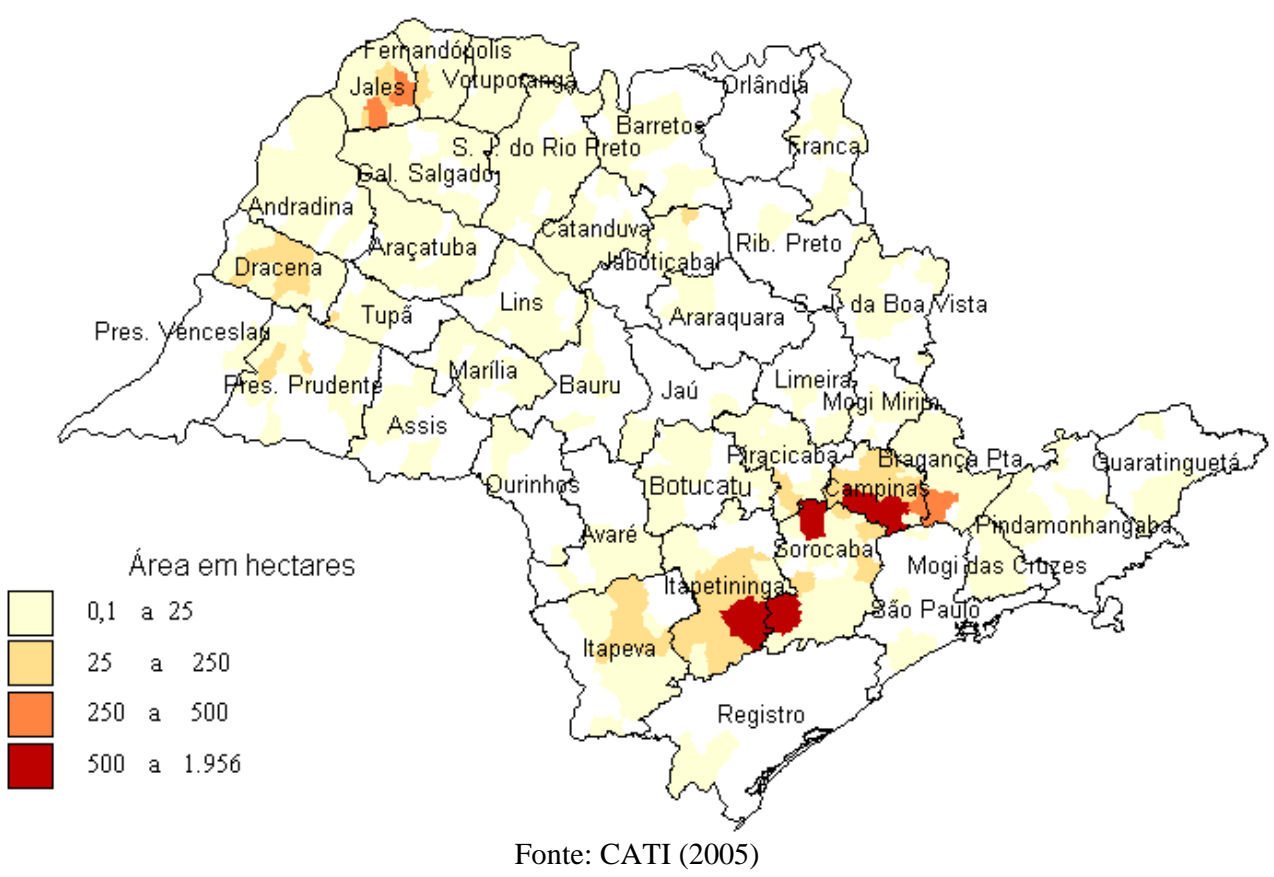

Figura 1 - Distribuição Geográfica da Cultura da Uva no Estado de São Paulo 
A Figura 1 mostra a distribuição geográfica da cultura da uva no Estado de São Paulo. As regiões de Campinas, Sorocaba e Itapetininga têm áreas de 500 a 1956 hectares plantados. Entretanto, a região de Campinas é a maior produtora de uvas comum, respondendo por cerca de $70 \%$ da produção e dos pés, sendo ainda nessa região que ficam os principais municípios produtores, ordenados no Quadro 1 segundo a quantidade produzida (Brasil, 2000).

\begin{tabular}{|lcccc|}
\hline \multicolumn{1}{|c}{ Município } & $\begin{array}{c}\text { Área colhida } \\
\text { (ha) }\end{array}$ & $\begin{array}{c}\text { Produção } \\
(\mathrm{t})\end{array}$ & $\begin{array}{c}\text { Produtividade } \\
\text { (t/ha) }\end{array}$ & $\begin{array}{c}\text { Participação na } \\
\text { Produção Nacional (\%) }\end{array}$ \\
\hline Jundiaí & 1.800 & 43.641 & 24,2 & 2,8 \\
Indaiatuba & 1.350 & 33.750 & 25,0 & 2,2 \\
São Miguel & 1.101 & 27.722 & 25,2 & 1,8 \\
Arcanjo & & & & \\
Pilar do Sul & 613 & 17.590 & 28,7 & 1,1 \\
Louveira & 703 & 16.000 & 22,8 & 1,0 \\
\hline
\end{tabular}

Adaptado de Mapeamento da Fruticultura Brasileira - 2000 (Brasil, 2000).

Quadro 1 - Principais Municípios Produtores de Uva no Estado de São Paulo

Na viticultura paulista as Niágaras são as uvas mais cultivadas, perfazendo uma área de 7.626 hectares, o que representa 66,3\% dos vinhedos (Ghilardi \& Maia, 2001).

São várias as doenças e pragas que atingem a videira. Com a introdução das espécies americanas e da prática de enxertia, muitas delas deixaram de ter importância. Entretanto, as cultivares européias, consideradas como nobres, estão sujeitas a várias doenças e sua produção só é possível com um programa intensivo de controle químico.

Dentre as doenças mais importantes que atacam a videira está o míldio, ou mufa, causada pelo fungo Plasmopara viticola (B.). É uma doença criptogâmica, pois impede a formação das flores e que ataca a planta por ocasião do seu desenvolvimento vegetativo. Existem vários produtos químicos recomendados para a prevenção e eliminação do míldio. Braga (1988) cita os fungicidas Captan, Zineb, Ziram, Maneb, Orthocide 50 e Acti-dione como preventivos e Metalaxil como curativo recomendados para a prevenção ou eliminação da doença. Nota-se, entretanto, que os produtores utilizam ainda em larga escala a calda bordalesa (mistura de sulfato de cobre e cal, 
diluídos em água) como produto químico preventivo à doença, sendo que a cultivar Itália necessita de 40 a 50 aplicações anuais (Murayama, 1980).

\subsubsection{A cultura do figo}

Assim como ocorre para a cultura da uva, a cultura da figueira no Brasil tem maior expressão econômica nos Estados do Rio Grande do Sul, São Paulo e Minas Gerais. Em 2003, a produção de figo no Brasil foi de 25,6 mil toneladas, sendo que mais de 93 \% da produção brasileira de figo está concentrada em três estados: Rio Grande do Sul com 47 \%, São Paulo com 28 \%, Minas Gerais com 20 \% e os demais estados com 7 $\%$ (IBGE, 2003).

Entre 1990 e 1996, foram erradicadas do Estado de São Paulo cerca de 1,5 milhão de figueiras e a produção de figo para indústria foi reduzida de $7.825 t$ para 402,2t; enquanto que a produção de figo para mesa caiu de 10,3 milhões de engradados para 1,7 milhão, no mesmo período. Tal redução da oferta para a indústria pode ser atribuída à mudança da principal compradora para o Estado de Goiás, permanecendo apenas indústrias menores na região. A partir de 1997, pequenos plantios proporcionaram modesto aumento do número de pés em produção e da produção paulista de figo para mesa. (Maiorano, 1999).

O Estado de S. Paulo é produtor de figo para mesa, destinada ao mercado interno, como figo maduro e ao externo como tipo exportação tipo verde ou meio maduro.

Atualmente a cultura de figo é de grande importância para pequenos produtores localizados na região de Campinas, principalmente no município de Valinhos, onde se localizam 51\% dos produtores e 73\% da produção de São Paulo, tendo atingido, em 2001, valor da produção superior a cinco milhões de reais em nível de produtor (Perez et al., 2003).

A introdução do figo em São Paulo se deu juntamente com a videira, marmeleiro, romãzeiras outras espécies, trazidas pelos participantes da primeira 
expedição de Martin Afonso de Souza em 1532, e logo se estabeleceram junto aos primeiros povoamentos no planalto paulista (CATI, 2003).

Até o inicio do século XX a cultura da figueira em São Paulo não havia despertado interesse comercial. Era cultivada apenas nos fundos de quintais e junto à sede dos sítios e fazendas. Somente a partir de 1910 passou a ser cultivada comercialmente na região compreendida pelo antigo distrito de Valinhos, ainda pertencente à Campinas, hoje município de Valinhos e conhecido como a Capital nacional do Figo Roxo.

O introdutor do figo Roxo em Valinhos foi o Sr. Lino Busatto, imigrante italiano que chegou ao Brasil por volta de 1898 e teve a iniciativa de mandar vir de uma região da Itália próxima ao Mar Adriático, algumas mudas de figueiras produtoras de figos roxo, que encontraram fácil adaptação. Tratadas com cuidado prosperaram e seus figos, de coloração roxo escura, tornaram-se desde logo conhecidos como "Roxo de Valinhos" (CATI, 2005).

A cultura da figueira está presente em 48 municípios no Estado de São Paulo, num total de 226 propriedades, perfazendo 550,5 hectares, para um numero de 749.759 plantas (Figura 2).

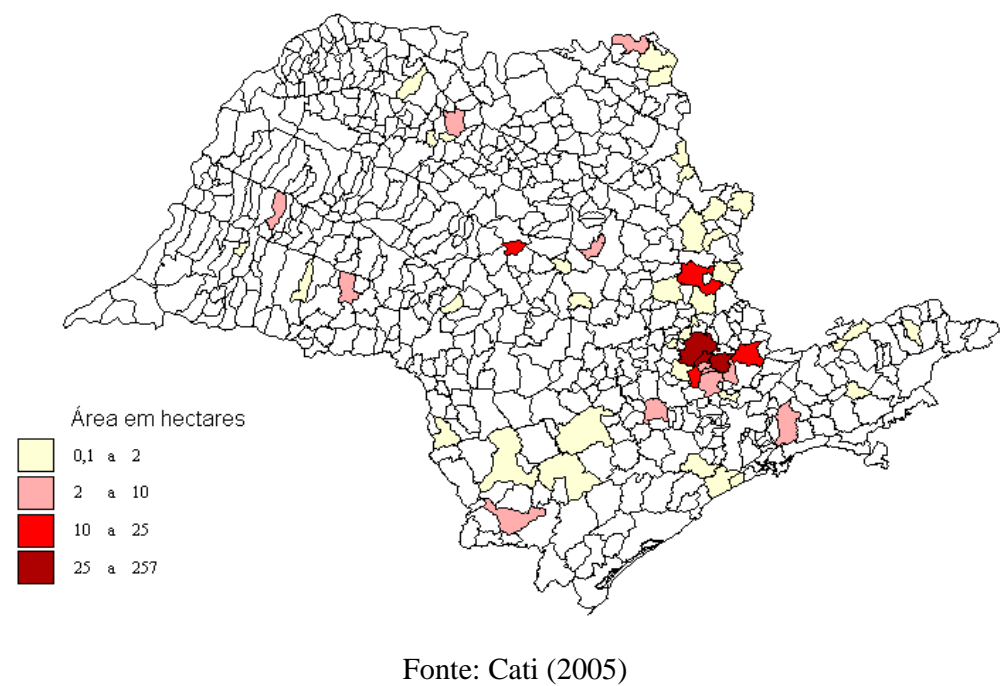

Figura 2 - Distribuição Geográfica Cultivo do Figo Roxo de Valinhos no Estado de São Paulo 
Assim como a uva, o figo também teve problemas quanto à ocorrência de pragas e doenças nas lavouras. As primeiras plantações eram muito atacadas por "brocas e ferrugem", que provocavam a queda prematura das folhas e o atrofiamento dos frutos, fazendo com que a safra nunca fosse além de Janeiro.

Graças à contribuição dada por instituições como Escola Superior de Agricultura "Luís de Queiroz” e do Instituto Biológico foram encontradas soluções para os problemas fitossanitários da cultura, possibilitando a ampliação da safra. Para isso foram adotadas práticas cuja condução persistem praticamente até hoje, tais como: recomendações de podas energéticas, destruição dos ramos podados e emprego de caldas fúngicas e inseticidas.

\subsection{Uso de calda bordalesa em frutíferas e conseqüências}

Segundo Ghini (2004) o uso de fungicidas é um dos principais métodos de controle de doenças de plantas e única forma de controle para diversos problemas fitossanitários. Seu uso é amplamente difundido em diversas culturas devido à facilidade de aplicação e aos resultados imediatos obtidos. Entretanto, o uso contínuo pode promover a seleção de fungos fitopatogênicos resistentes, não mais controlados pelo fungicida anteriormente eficaz, colocando em risco a eficiência do método. Conseqüentemente o surgimento de fungos fitopatogênicos resistentes a fungicidas torna-se um sério problema que pode por em risco o controle dessas doenças de plantas.

Neste caso, pode ser útil o uso de defensivos alternativos, alguns de preparação caseira, elaborados a partir de substâncias não prejudiciais à saúde humana e ao meio ambiente, quando manipulados corretamente. Os defensivos alternativos pertencem a um grupo de formulações que têm como características não favorecer a ocorrência de formas de resistência a fitoparasitas ${ }^{1}$, baixa toxicidade ao homem e à natureza, eficiência no combate a artrópodes e microrganismos nocivos, disponibilidade e custo reduzido. Estão

\footnotetext{
${ }^{1}$ Fitoparasita - organismo que, pelo menos em uma fase de seu desenvolvimento, se encontra ligado à superfície ou ao interior de uma planta, dita hospedeira, do qual obtém a totalidade ou parte de seus nutrientes.
} 
incluídos na categoria, entre outros, os diversos biofertilizantes líquidos, as caldas Sulfocálcica, Viçosa e Bordalesa, os extratos de plantas e os agentes de biocontrole (Penteado, 1999).

O princípio destas caldas não é erradicar os insetos ou patógenos, porém aumentar a resistência e a repelência das plantas. Desta forma, as caldas bordalesa e sulfocálcica constituem os principais meios de controle alternativo de pragas e doenças para as plantas cultivadas no processo ecológico e orgânico. O uso dessas caldas é permitido pela Agricultura Orgânica. A Instrução Normativa ${ }^{\circ}$ 7, de 17 de maio de 1999 do Ministério da Agricultura, Pecuária e Abastecimento dispõem sobre normas para a produção de produtos orgânicos vegetais e animais. Ela foi estabelecida considerando a crescente demanda de produtos obtidos por sistemas ecológicos, biológicos, biodinâmicos e agroecológico, a exigência de mercado para tais produtos. Assim, ela estabelece as normas de produção, tipificação, processamento, envase, distribuição, identificação e certificação da qualidade de produtos orgânicos, sejam de origem animal ou vegetal. No que concerne aos meios contra doenças fúngicas, as seguintes opções são mencionadas no Anexo III - Produção Vegetal (Brasil, 2004), da referida instrução: Enxofre simples e suas preparações, a critério da certificadora; Pó de pedra; Um terço de sulfato de alumínio e dois terços de argila (caulim ou bentonita) em solução a 1 \%; Sais de cobre, na fruticultura; Própolis; Cal hidratado, somente como fungicida; Iodo; Extratos de plantas; Extratos de compostos e plantas; Vermicomposto; Homeopatia; Calda bordalesa e calda sulfocálcica, a critério da certificadora.

No século XIX, na região de Bourdeaux, na França, surgiu à calda bordalesa, fungicida usado para o controle de míldio em videiras. A descoberta acidental em 1882 na França, de que a calda, resultante da neutralização de sulfato de cobre com excesso de hidróxido de cálcio aspergido sobre vinhedos, além de evitar coleta furtiva, pelo aspecto azulado conferido à folhagem, era ativa contra o míldio da videira, foi o marco histórico decisivo para início do controle químico de doenças de plantas (Michereff, 2004).

A calda bordalesa é uma suspensão coloidal obtida na mistura de sulfato de cobre pentahidratado $\left(\mathrm{CuSO}_{4} \cdot 5 \mathrm{H}_{2} \mathrm{O}\right)$ e suspensão de cal virgem $(\mathrm{CaO})$, que reagindo com água forma $\mathrm{Cu}(\mathrm{OH})_{2}$, proporcionando um meio alcalino. Nessas condições, forma- 
se um precipitado gelatinoso azulado de hidróxido de cobre, praticamente insolúvel em água, estabilizado pela adsorção ao sulfato de cálcio, também produzido na mistura. O hidróxido de cobre forma membranas de precipitação em torno dessas partículas. De acordo com a tecnologia de preparo a mistura produz vários compostos tais como: hidróxido de cobre, sulfato de cobre, sulfato de cálcio, sulfato básico de cobre e sulfato básico duplo de cobre e cálcio (Penteado, 2000). A preparação mais comum da calda bordalesa se dá na proporção de 1 parte de cal virgem e 1 parte de sulfato de cobre para 100 partes de água. A quantidade de cada ingrediente vai depender do volume final de calda pretendido.

Atualmente o uso da calda bordalesa vem se intensificando em culturas perenes principalmente as frutíferas. Epstein \& Bassein (2001), estudando a aplicação de pesticidas de cobre em culturas perenes na Califórnia de 1993 a 1998, observaram que a intensidade do uso do $\mathrm{Cu}$ na Califórnia tem sido relativamente constante ou crescente, dependendo da cultura. Das doze culturas estudadas, grande aumento na intensidade do uso do $\mathrm{Cu}$ ocorreu nos vinhedos, onde houve um aumento de $70 \%$ em termos de $\mathrm{kg} \mathrm{Cu}$ $\mathrm{km}^{-2}$ de área plantada, enquanto a área cultivada com vinhedos aumentou em $10 \%$ no mesmo período.

O acúmulo de cobre em alguns solos agricultáveis acima das quantidades que são requeridas para o crescimento saudável da planta tem gerado numerosos estudos, os quais indicam que o uso prolongado de produtos a base de cobre resulta freqüentemente na contaminação do solo. Li (1994), estudando o efeito em longo prazo da aplicação de calda bordalesa na cultura da uva em solos da planície costeira no oeste da China, observou que o teor de Cu extraído por DTPA era de $34,2 \mathrm{mg} \mathrm{kg}^{-1}$ na superfície do solo em que se cultivavam uvas por 10 anos.

Florez-Vélez et al. (1996) estudando a distribuição do cobre em um solo arenoso ácido de vinhedo na Franca, verificou que o uso da calda bordalesa como fungicida para o controle do míldio em vinhedo, resultou numa acumulação significativa de Cu no solo de 100 a $1500 \mathrm{mg} \mathrm{kg}^{-1}$.

Deluisa et al. (1996) em seu trabalho sobre a poluição de cobre em solos italianos de vinhedo, verificou que em áreas cultivadas com vinhedos e onde se usava 
fungicida cúprico, o cobre acumulava-se no perfil do solo em maior quantidade na camada superficial do solo e diminuía quando atingia as camadas mais profundas. A concentração média do $\mathrm{Cu}$ na camada superficial era, de acordo com o método de extração utilizado, de aproximadamente quatro (Água Régia), cinco (DTPA) e dois e meia $\left(\mathrm{CaCl}_{2}\right)$ vezes maior que a de $\mathrm{Cu}$ encontrado nas camadas mais profundas.

\subsection{Comportamento do cobre no solo}

Cobre é um metal maleável, dúctil, de cor vermelha, excelente condutor de eletricidade e extraído de minérios. Apresenta densidade igual a $8,96 \mathrm{~g} \mathrm{~cm}^{-3}$, que por ser superior a $5 \mathrm{~g} \mathrm{~kg}^{-1}$ o caracteriza como um metal pesado (Malavolta, 1994). Na Tabela periódica o cobre se localiza no grupo 1B, sendo um metal de transição externa.

Grande parte do cobre da litosfera está combinada com o enxofre na forma de sulfeto de cobre, que ocorre em rochas principalmente como sulfetos complexos, facilmente intemperizados e liberam íons $\mathrm{Cu}^{2+}$, especialmente em meio ácido (Raij, 1991). É graças ao material de origem, à mineralogia e ao conteúdo da matéria orgânica que o cobre ocorre em diversas formas no solo e se distribuí entre elas. O cobre ocorre nos solos adsorvido à superfície dos minerais de argila, óxidos de $\mathrm{Fe}, \mathrm{Al}$ e $\mathrm{Mn}$ e matéria orgânica.

O teor médio de Cu na litosfera é de $70 \mathrm{mg} \mathrm{kg}^{-1}$, sendo geralmente encontrados nos solos valores entre 2 e $100 \mathrm{mg} \mathrm{kg}^{-1}$ para teores totais e uma faixa de 1 a $8 \mathrm{mg} \mathrm{kg}^{-1}$ para teores solúveis. No Estado de São Paulo, os teores totais situam-se entre 2 a $340 \mathrm{mg}$ $\mathrm{kg}^{-1}$, enquanto que os teores solúveis variam entre 0,08-0,80 mg kg-1 (Camargo et al., 2001).

Geralmente o cobre é um elemento com pouca mobilidade nos solos, no entanto, os solos ácidos com baixo teor em matéria orgânica podem ser uma exceção. O cobre tende a acumular-se no horizonte superficial dos solos e, assim como para os demais metais encontrados em solos de regiões agrícolas, o aumento das concentrações é 
resultado da deposição atmosférica, da aplicação de agrotóxicos, resíduos orgânicos e inorgânicos, fertilizantes e corretivos (Alloway,1995).

É notável o papel da matéria orgânica para mobilização do cobre no solo. A relação do cobre com a matéria orgânica do solo é especialmente importante devido à elevada afinidade do elemento por compostos orgânicos, formando complexos solúveis e insolúveis.

A complexação de metais pela matéria orgânica em solos e ambientes aquáticos é considerada um dos principais mecanismos que governam a solubilidade e biodisponibilidade de metais no sistema solo-planta (Ross, 1994). O cobre se fixa à matéria orgânica no horizonte superficial através de complexação do elemento pelos ácidos húmicos e ácidos fúlvicos que permitem, pela sua presença, a retenção do cobre nos solos.

O alto grau de seletividade da matéria orgânica para com o Cu é causado pela formação de complexos de esfera interna, também referido como adsorção específica (Guilherme e Anderson, 1998). Em baixas concentrações de Cu na solução, este será imobilizado principalmente pelos ácidos húmicos, mas à medida que os sítios de ligação forte vão sendo saturados, uma quantidade maior de $\mathrm{Cu}$ será solubilizada pelos ácidos fúlvicos ou por compostos orgânicos mais simples (McBride, 1989).

Quando adsorvido, o cátion $\mathrm{Cu}^{2+}$ pode participar de uma interação de natureza eletrostática não especifica e então se refere ao elemento como estando na forma trocável. Na solução do solo o cobre pode existir na forma catiônica livre, $\mathrm{Cu}^{2+}$, ou na foram complexada.

A concentração de cobre na forma catiônica livre na solução do solo é extremamente baixa devido à afinidade que o elemento tem por compostos orgânicos. Nolan et al. (2003), aplicando a técnica do equilíbrio de Donnan em solos contaminados, observaram que nos extratos de saturação a proporção de cobre na forma catiônica livre era 1,2 \% do cobre total dissolvido. Do mesmo modo, Vulkan et al. (2000) detectaram concentrações relevantes de cobre na forma $\mathrm{Cu}^{2+}$ apenas em extratos de saturação de solos com pH menor que 6 e com baixos teores de carbono orgânico dissolvido. 
Embora a concentração de cobre total nos solos seja um indicador útil da deficiência ou da contaminação do solo, não fornece informações conclusivas sobre seu impacto ambiental. A disponibilidade de cobre à biota, seja como um nutriente ou como um elemento tóxico, e sua mobilidade são os fatores mais importantes a serem considerados ao avaliar seu efeito no ambiente do solo.

Os efeitos referentes à mobilidade, biodisponibilidade e toxicidade dos metais nos solos dependem das formas que o metal ocorre nos mesmos (Tessier et al., 1979; Tessier \& Campbell, 1988; Karczewska, 1996 e McLaughlin et al., 2000). Essas formas, ou frações do solo em que os metais se encontram, podem ser identificadas operacionalmente por procedimentos de extração seqüencial, que utilizam uma série de reagentes com força solubilizante crescente (Lake et al., 1984). O princípio do fracionamento baseia-se na premissa de que elementos cada vez mais imóveis na fração sólida do solo poderem ser extraídos por reativos cada vez menos seletivos (Viets, 1962).

De acordo com Pierrisnard (1996), a extração seqüencial é uma das três formas de efetuar a extração de elementos em amostras de solo. As extrações únicas que envolvem uma amostra e um extrator, ou mistura de extratores, são rápidas, econômicas e dão uma noção dos teores de elementos removidos por determinados reagentes. Entretanto, as reações envolvidas são influenciadas pela relação sólido-extrator, tempo de extração e mudanças de pH e ainda pode ocorrer precipitação de metais durante o processo. As extrações paralelas são realizadas com várias amostras de solo, submetidas a ação de diferentes reagentes. Se por um lado, não estão sujeitas ao acúmulo de erros do sistema de extração anterior, apresentam o inconveniente de exigir várias extrações do teor residual. As extrações seqüenciais são as mais usadas para metais e consistem em extrações sucessivas executadas em uma única amostra, utilizando extratores cada vez mais efetivos. Dentre as extrações descritas, esta é considerada como a que fornece informações mais precisas sobre a distribuição de metais nas frações da fase sólida, possibilitando inferir sobre a disponibilidade desses elementos.

Diversos fatores podem interferir nos métodos de fracionamento. Dentre esses estão: relação sólido-extrator, seqüência de extração, seletividade dos extratores usados, 
tempo de contato entre a amostra e o extrator e reabsorção ou precipitação de metais durante o processo de extração (Ross, 1994).

Sposito et al. (1982) e Ross (1994) destacam a importância da escolha de extratores seletivos e da marcha de extração no desenvolvimento dos métodos de fracionamento. A baixa seletividade dos extratores faz com que estes ataquem mais de uma fração ao mesmo tempo, interferindo no equilíbrio das extrações posteriores. Este inconveniente é um dos maiores problemas dos métodos de fracionamento, pois prejudica a eficiência da extração e a confiabilidade dos resultados.

Inúmeros esquemas de fracionamento têm sido testados. Tal variação de procedimentos se deve ao fato de serem aplicáveis a materiais com características físicoquímicas muito diversas, como tipos diferentes de solos e sedimentos. Na maioria dos trabalhos envolvendo fracionamento, o procedimento pode ser apenas uma adaptação de métodos anteriores, desenvolvidos muitas vezes para outras matrizes. Para a correta escolha ou adaptação do método a ser utilizado, é imprescindível o conhecimento das características da matriz de onde serão extraídos os metais.

Quantificando o teor de cobre e de outros metais nas suas diferentes frações nos solos contaminados, e comparando com suas condições naturais, pode-se avaliar a extensão da ação do homem no ambiente e os riscos a ela associados.

Para estudar a distribuição de metais pesados em 11 solos da Espanha, Cañadas et al. (1986) realizaram o fracionamento das amostras segundo Tessier et al. (1979). Os autores verificaram que o $\mathrm{Cu}$ e o $\mathrm{Cr}$ se ligam preferencialmente aos óxidos de ferro e manganês, exceto em solos com teores elevados de matéria orgânica. Nesta condição, tais metais foram encontrados associados à fração matéria orgânica. $\mathrm{O} \mathrm{Pb}$ e o $\mathrm{Cd}$ apareceram nas formas mais disponíveis como a trocável e a ligada a carbonatos.

No Brasil, Amaral Sobrinho et al. (1997) realizaram o fracionamento de metais em amostras de solo incubadas com resíduos de siderúrgicos, também utilizando a metodologia de Tessier et al. (1979) sem a extração da fração trocável. Os autores verificaram que todos os metais adicionados passaram para formas menos disponíveis (frações óxido e residual), sendo $\mathrm{Ni}, \mathrm{Cd}$ e $\mathrm{Cu}$ os mais encontrados na fração residual. Os 
próprios autores identificaram um inconveniente no método: a extração do $\mathrm{Pb}$ da fração óxidos pelo extrator da fração carbonato.

Quando um material é incorporado ao solo, os elementos nele presentes são incorporados sob diferentes formas químicas, próprias desse material. Em função do tempo de incorporação e das condições do meio, esses componentes podem sofrer graus variáveis de transformação até que possam ser considerados como fazendo parte integrante do solo e não mais do material originalmente aplicado. Em muitos casos torna-se difícil precisar exatamente quando essa transição ocorreu.

Ao analisar o comportamento do cobre proveniente da calda bordalesa, deve-se levar em conta que é um material inorgânico e que apresenta pH elevado. Contudo, uma vez incorporado ao solo, o cobre proveniente desse fungicida poderá interagir com a fração orgânica do solo e a fração “cobre ligado à matéria orgânica” certamente terá importância, apesar da fonte do metal ser de natureza inorgânica. Isso se deve à elevada afinidade do cobre por ligantes orgânicos, conforme salientado anteriormente.

Parat et al. (2002) investigaram o comportamento do cobre em solos do vinhedo para demonstrar a contribuição da matéria orgânica e de componentes organo-minerais como fases possíveis para o $\mathrm{Cu}$, e efeitos dos altos teores do $\mathrm{Cu}$ em solos do vinhedo. No fracionamento, realizado em 10 amostras do solo de superfície da região francesa da Borgonha, observaram que o cobre se concentrou principalmente na fração dos óxidos amorfos de ferro. As quantidades presentes nas frações residual, orgânica e ligada a óxidos cristalinos do ferro ocorreram em valores intermediários. Entretanto, as maiores quantidades de $\mathrm{Cu}$ estavam ligadas à matéria orgânica e foram provenientes das amostras onde o solo estava mais contaminado.

Em solos brasileiros, Nogueirol et al. (2004), realizaram fracionamento em amostras de dois solos do Rio Grande do Sul, cultivados por mais de 15 anos com uva que recebeu aplicações de fungicida cúprico. Verificaram que ambos os solos mostraram teores elevados de cobre, sendo que a maior parte do elemento estava associada à matéria orgânica, em proporções variando de 70 a 80\%.

A fração de cobre do solo que realmente tem significância à vida vegetal é aquela chamada disponível, ou seja, acessível para ser absorvida pelas raízes das plantas. 
A fração disponível pode ser associada ou correlacionada com índices geralmente obtidos por métodos de extração química. As dificuldades no estabelecimento desses índices são maiores para os micronutrientes, devido aos baixos teores no solo e aos mecanismos que governam as reações de disponibilidade (Abreu et al., 2001).

A disponibilidade dos íons metálicos na solução do solo depende de uma série de fatores, tais como: pH, CTC, teor de matéria orgânica, textura e composição do solo, competição por outros cátions pelos sítios de absorção, etc (Hooda e Alloway, 1996).

Lopes \& Carvalho (1988) analisando critérios de diagnose de micronutrientes para solo e planta verificaram que a maior disponibilidade de cobre está na faixa de $\mathrm{pH}$ 5,0 a 6,5. Destacam os autores, que os solos orgânicos, apesar de apresentarem abundância desse elemento, são os mais prováveis de apresentarem deficiência de cobre, pois esse metal forma complexos tão estáveis com a matéria orgânica, que somente pequenas quantidades são disponíveis para as plantas. Já os solos arenosos, com baixos teores de matéria orgânica, podem se tornar deficientes em cobre em função de perdas por lixiviação. Os solos argilosos, por sua vez, apresentam menores probabilidades de apresentarem deficiência. A presença excessiva de outros íons metálicos, como ferro, manganês e alumínio, reduz a disponibilidade de cobre para as plantas, efeito esse que independe do tipo de solo.

O sucesso da monitoração de metais pesados no solo depende, em grande parte, de um método químico eficiente para medir a fração desses elementos colocada à disposição das plantas. Entre os extratores universais mais utilizados no diagnóstico da disponibilidade de elementos no solo, estão DTPA, Mehlich 1 e Mehlich 3 (Raij, 1994).

Mantovani et al. (2004) estudaram extratores para avaliação da disponibilidade de metais pesados em solos adubados com vermicomposto produzidos a partir de lixo urbano e concluíram que o DTPA extraiu maiores quantidades de $\mathrm{Cu}$. Os autores também constataram que o DTPA foi o único extrator que detectou efeito significativo da aplicação do vermicomposto e da calagem nos teores de todos os metais pesados analisados: $\mathrm{Ni}, \mathrm{Pb}, \mathrm{Cu}, \mathrm{Mn}$ e Zn. Quanto ao extrator Mehlich 1, não foi constatado efeito do vermicomposto nos teores de $\mathrm{Cu}$ no solo. 
Nogueirol et al. (2003), avaliando extratores de cobre em solos da região da Serra do RS, cultivados por vinhedos por mais de 15 anos, observaram que os teores de $\mathrm{Cu}$ extraído por DTPA diminuíram com o aumento do $\mathrm{pH}$, tanto no Neossolo Litólico distrófico típico (RLd), como no Cambissolo Húmico alumínico típico. Entretanto, para os extratores $\mathrm{CaCl}_{2}$ e Mehlich III houve aumento dos teores de $\mathrm{Cu}$ com a diminuição do $\mathrm{pH}$.

\subsubsection{Método de Neubauer}

Um teste relativamente rápido para avaliação de disponibilidade de nutriente às plantas pode ser implementado por meio do chamado experimento de Neubauer que apresenta a vantagem de ser um método biológico de determinação da quantidade disponível de elementos no solo.

A técnica original e a interpretação dos dados obtidos pela mesma são descritas por Neubauer \& Schneider $^{2}$ e Vandecaveye ${ }^{3}$, citados por Catani \& Bergamin Filho (1961). O método baseia-se na idéia de que um grande número de plântulas crescendo num volume pequeno de terra absorverá toda quantidade de nutrientes disponíveis num pequeno espaço de tempo (Mello et al., 1983).

Experimentos de Neubauer são especialmente adequados para comparação de procedimentos de extração de nutrientes do solo. Grzebisz \& Oertli (1993) usaram a técnica para avaliar o comportamento de sete extratores, entre os quais a solução de DTPA, na determinação de potássio disponível em dezoito solos.

Materechera (1999) usaram plântulas de trigo que se desenvolveram por 21 dias para correlacionar teores disponíveis determinados com extratores químicos com a absorção pelas plantas, encontrando maiores coeficientes de correlação para

\footnotetext{
${ }^{2}$ NEUBAUER, H.; SCHNEIDER. Die nährstoffaufnahme der keimpflanzen und ihre anwendung auf bestimmung des Nahrstoffgehalts der Böden. Zeitsch. Pflazenernährung und Düngung, 2A, p.329-362, 1923.

${ }^{3}$ VANDECAVETE, S.C. Biological methods of determining nutrients in soil. In: KITCHEN, H.B. (Ed.). Diagnostic techiniques for soils and crops. Washington: The American Potash Institute, 1948. p.119-230.
} 
macronutrientes e zinco do que para demais micronutrientes. $\mathrm{O}$ autor comenta que, a despeito da dificuldade de extrapolação para condições de campo, a técnica de Neubauer oferece uma forma barata e rápida se relacionar teores disponíveis de nutrientes com absorção e crescimentos de plantas.

Da mesma forma, Rupa \& Shukla (1999) avaliaram a disponibilidade as plantas dos elementos cobre e zinco diversos extratores inclusive o DTPA, usando o experimento de Neubauer.

Também usando um experimento tipo Neubauer, Yu et al. (2004) conseguiram estabelecer uma extração por meio de resina de troca iônica para estimar o teor de Cr (VI) no solo com o objetivo de avaliar a fitotoxicidade desta forma de cromo às plantas.

O experimento de Neubauer pode ser empregado não apenas em estudos envolvendo solo. Vale \& Alcarde (1999) utilizaram a técnica citada com o objetivo de determinar a solubilidade dos micronutrientes em fertilizantes simples comerciais, pelo uso de extratores químicos, correlacionando-a com a absorção por plantas. Neste trabalho, as fontes de micronutrientes foram misturadas apenas à areia.

\subsubsection{Relações entre alguns materiais e compostos orgânicos e o comportamento de metais no solo}

Tendo em vista que no presente estudo se considerou o efeito de alguns materiais e compostos orgânicos na mobilização do cobre no solo, serão discutidos a seguir alguns trabalhos referentes à ação dos mesmos.

\subsubsection{Sistema Ácido Cítrico/Citrato}

Reagentes químicos geralmente são utilizados como extratores de metais pesados para avaliação de sua fitodisponibilidade em solos tratados com materiais que contem aqueles elementos. Muitas soluções extratoras normalmente não chegam a simular as reações que ocorrem próximas às raízes, resultando numa avaliação da 
fitodisponibilidade dos metais pouco precisa. Ácidos orgânicos de baixo peso molecular liberados pelas raízes das plantas têm importante papel na solubilização dos metais pesado originários de materiais como biossólidos (Marschner, 1995).

O ácido cítrico é citado como sendo o mais abundante ácido orgânico na rizosfera. É um ácido orgânico tricarboxílico, largamente distribuído nas plantas e nos fluidos e tecidos animais, cuja formula é:<smiles>O=C(O)CC(O)(CC(=O)O)C(=O)O</smiles>

Suas constantes de ionização, expressas em termos de pKa, são sucessivamente: 3,13; 4,76 e 6,40 (Harris, 1995). Pode-se dizer assim, que uma solução de ácido cítrico ajustada a pH 6,4 conterá 50\% de íons citrato e 50\% de íon dihidrogênio citrato. A pH acima de 9 se tem praticamente apenas o ânion citrato trivalente em solução.

Jones et al. (1996) sugeriram que os ácidos orgânicos representam a maior proporção em relação aos demais componentes dos exudatos radiculares. O acido cítrico aparece em concentrações relevantes nos exudatos radiculares, sendo por vezes citado como o mais abundante dos compostos presentes (Gardner et al., 1983; Li et al., 1997). Os ácidos orgânicos que são excretados pelas raízes das plantas e participam de mecanismos importantes de disponibilização de nutrientes (Marschner, 1995).

Ahumada (2001) observou que a adição de ácidos orgânicos a solos contaminados com cádmio e cobre promoveu alteração nas frações em que esses metais se distribuíam. A presença de íon citrato afetou as frações de cobre trocável, ligada a carbonatos e associadas a óxidos de manganês.

Soluções de íon citrato têm sido estudadas na remediação de solos contaminados com metais pesados. Arevalo et al. (2002) conseguiram a remoção de $80 \%$ do chumbo presente em solo contaminado por industria de baterias com solução $0,13 \mathrm{~mol} \mathrm{~L}^{-1}$ de íon citrato a $\mathrm{pH}$ 5,0. Para resolver esse mesmo tipo de problema, Tawinteung (2005) concluindo que 85, 84 e 74\% do chumbo presente foi removido por EDTA (relação molar 2:1 EDTA : Pb) e soluções $1 \mathrm{~mol} \mathrm{~L}^{-1}$ de $\mathrm{HNO}_{3}$ e $0.2 \mathrm{~mol} \mathrm{~L}^{-1}$ de 
citrato de amônio, respectivamente, após percolação com volume correspondente a 20 volumes de poro.

A remoção de cobre e cádmio de solos contaminados com soluções de ácidos orgânicos foi estudada por Gao et al., (2003). Verificaram diferenças marcantes entre o comportamento dos íons citrato e tartarato, sob variações de $\mathrm{pH}$, concentração do íon e de outros eletrólitos presentes.

Molinari .. (2005), empregaram o processo de ultrafiltração com membrana para remoção de metais pesados que tinham sofrido complexação do ácido cítrico, tendo trabalho com solos contaminados por cobre. Estabeleceram as condições químicas ideais para a complexação do cobre pelo ácido cítrico, determinados por meio de experimentos realizados com concentrações de $800 \mathrm{mg} \mathrm{L}^{-1}$ de ácido cítrico e de $200 \mathrm{mg} \mathrm{L}^{-1}$ de cobre. Os resultados mostraram que o processo de complexação do íon de cobre pelo ácido cítrico tem eficiência máxima entre pH 5 e 6, enquanto que a descomplexação ocorre em $\mathrm{pH}$ igual ou menor que 2. Determinaram também que a quantidade máxima de cobre que pode ser quelatada por $800 \mathrm{mg}$ ácido cítrico $\mathrm{L}^{-1}$ é igual a $500 \mathrm{mg} \mathrm{Cu} \mathrm{L}^{-1}$, dando uma condição de saturação de $0,625 \mathrm{mg} \mathrm{Cu}^{2+}$ por mg de ácido cítrico $\left(2 \mathrm{~mol} \mathrm{de} \mathrm{Cu}^{2+}\right.$ por mol de ácido cítrico).

No âmbito das análises químicas de insumos de interesse agronômico, o íon citrato tem grande importância na análise de fertilizantes, tendo sido também empregado na análise de solo.

A solução neutra de citrato de amônio (CNA) é uma solução tampão relativamente concentrada, utilizada com o pH ajustado a 7 . Surgida em 1871, é atualmente adotada na avaliação dos adubos fosfatados, determinando com maior exatidão o fosfato assimilável dos fosfatos acidificados como superfosfatos simples e triplo, os fosfatos amoniados, como MAP e DAP, entre outros (Vale, 2000).

Almeida (1999) cita que ao solução de CNA a 1\% (m/v) foi utilizada por Bernard Dyer em 1894 para extrair potássio e fósforo de solos, sendo provavelmente um dos mais antigos extratores de solos que se tem conhecimento.

Alcarde \& Ponchio (1979) demonstraram, com bases nas constantes de estabilidade do ânion citrato, a habilidade que o CNA, ao pH neutro, tem em formar 
complexos com cátions presentes numa matriz e passiveis de serem disponibilizados, entre os quais podem ser citados: $\mathrm{Ca}, \mathrm{Cu}, \mathrm{Fe}, \mathrm{Mg}, \mathrm{Mn}$, Na e $\mathrm{Zn}$. Os autores ressaltam a capacidade desse extrator em solubilizar os micronutrientes metálicos.

Objetivando determinar a solubilidade dos micronutrientes presentes em formulações NPK comerciais, Alcarde e Vale (2003) testaram vários extratores químicos, inclusive soluções contendo o íon citrato, concluindo que os micronutrientes $\mathrm{B}, \mathrm{Zn}, \mathrm{Fe}, \mathrm{Cu}$ e $\mathrm{Mn}$, contidos em formulações de fertilizantes, solubilizaram-se diferentemente nos extratores: água, solução de ácido cítrico a $20 \mathrm{~g} \mathrm{~L}^{-1}$ e solução neutra de citrato de amônio (1+9).

Apesar de sua capacidade extratora em solubilizar micronutrientes em fertilizantes seja conhecida, há poucas pesquisas sobre o uso do citrato de amônio como extrator de metais pesados.

\subsubsection{EDTA}

A sigla EDTA representa o ácido etilenodiaminotetracético, o agente quelante sintético mais conhecido e utilizado para diferentes aplicações industriais, agrícolas, entre outras.

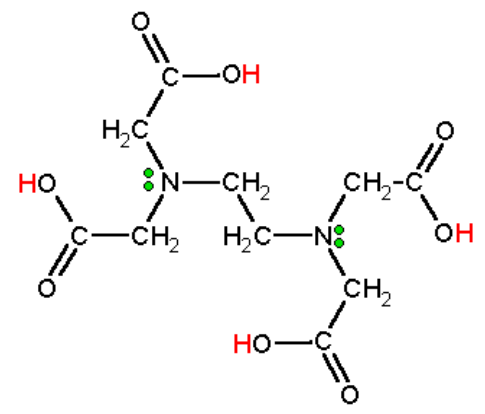

Figura 3 - Molécula do EDTA

O EDTA se coordena a íons metálicos por meio de pares de elétrons não compartilhados localizados nos átomos de nitrogênio dos dois grupos amino e nos átomos de oxigênio de cada um dos quatro grupos carboxílicos (Figura 3). 
A afinidade de um agente quelante por íons metálicos é expressa numericamente por sua constante de formação $K_{f}$, ou por simplicidade pelo $\log K_{f}$. Diversos íons metálicos de interesse agronômico como micronutrientes tem constantes de formação relativamente elevadas tais como: $\mathrm{Fe}^{3+}, 25,1 ; \mathrm{Cu}^{2+}, 18,8 ; \mathrm{Zn}^{2+}, 16,5 ; \mathrm{Fe}^{2+}$, 14,32; $\mathrm{Mn}^{2+}$, 13,87; todas expressas como $\log \mathrm{K}_{\mathrm{f}}$.

A formação de quelatos de íons metálicos com EDTA é dependente do pH do meio. O equilíbrio de dissociação do ácido EDTA de certa forma compete como ao equilíbrio de formação de complexos. De maneira geral, portanto, o abaixamento do $\mathrm{pH}$ do meio tende a prejudicar a formação de quelatos de EDTA com íons metálicos. Contudo, a extensão desse prejuízo vai depender da magnitude da constante de formação do quelato em consideração. Deste modo, quelatos de $\mathrm{Fe}^{3+}$ e de $\mathrm{Cu}^{2+}$ são estáveis mesmo em condições de pH baixo. No sentido oposto, a elevação de $\mathrm{pH}$ também pode afetar a formação de quelatos, mas agora em função do confronto entre o equilíbrio de formação de quelatos e o equilíbrio de precipitação dissolução dos hidróxidos dos cátions metálicos envolvidos. Se a tendência de precipitação de um cátion metálico for elevada, um quelato metálico será destruído devido à formação de um hidróxido muito pouco solúvel.

O EDTA é comercializado na forma de ácido, $\mathrm{H}_{4}$ EDTA, que apresenta a desvantagem de ser um composto muito pouco solúvel. Mais comumente são empregados seus sais de cálcio e de sódio como: $\mathrm{NaH}_{2}$ EDTA ou $\mathrm{Na}_{4} E D T A$, que são solúveis em água.

O EDTA foi o primeiro agente sintético usado para manter ferro solúvel em soluções hidropônicas, embora sua efetividade seja limitada a $\mathrm{pH}$ inferior a 6,5 pelas razões expostas anteriormente. Como as aplicações ao solo são restritas a solos ácidos e ligeiramente ácidos, fica impedido seu uso para controlar deficiência de micronutrientes em solos calcários onde elas são mais severas. Quelatos Fe-EDTA são usados rotineiramente em aplicações foliares como fonte de micronutrientes (Rodella et al., 2003).

Vassil et al. (1998) estudando o papel do EDTA no transporte e na acumulação de $\mathrm{Pb}$ em mostarda indiana (Brassica juncea L.) observou que o processo é baseado na 
habilidade que o EDTA tem em transportar Pb para o tecido da planta. Realmente, o EDTA é um dos quelatos mais eficazes em aumentar a absorção de vários metais, inclusive o cobre (Deram et al., 2000).

As aplicações de quelatos podem aumentar o risco de poluição da água promovendo solubilização descontrolada do metal e lixiviação. Embora alguns estudos mencionem o risco do metal ser lixiviado para alem da zona da raiz, pouca atenção foi dada à quantificação de tal lixiviação. Uma exceção é o trabalho de Grêcman et al. (2001) mostrando que o EDTA aumentou a absorção de metais pesados por Brassica rapa e resultou também na perda por lixiviação de 38, 10 e 56\% de Pb, Zn e Cd, respectivamente, presente em colunas de solo.

Thayalakumaran et al. (2003), investigando a absorção por planta e de lixiviação do cobre pela adição do EDTA, observaram que a aplicação de EDTA aumentou a concentração do cobre na planta de 30 a $300 \mu \mathrm{g} \mathrm{g}^{-1}$. Uma maior quantidade de cobre foi acumulada quando o EDTA era aplicado em diversas doses pequenas, do que em apenas uma ou duas aplicações.

Através de experimento em colunas, Wu et al. (2004) estudaram a fitoextração de metais pesados por mostarda da Índia (Brassica Juncea) sob a influência de EDTA na dose de $3 \mathrm{mmol} \mathrm{kg}^{-1}$, bem como a dos ácidos cítrico, málico, e oxálico. A adição de EDTA aumentou a mobilidade de $\mathrm{Cu}$, e $\mathrm{Pb}$ mas não de $\mathrm{Zn}$ e Cd, e também aumentou as concentrações dos metais na planta. A adição dos outros ânions orgânicos citados não afetou a absorção de metais pela planta. Em experimento de lixiviação, as concentrações dos metais $\mathrm{Pb}, \mathrm{Cu}$, Zn Cd e de carbono orgânico no lixiviado aumentou linearmente em função da dose de EDTA aplicada ao solo em doses entre 0 e $12 \mathrm{mmol} \mathrm{kg}{ }^{-1}$.

A ocorrência de EDTA no ambiente causa preocupação por constituir uma forma de mobilização de metais pesados pela formação de complexos solúveis. Quando usado na fitorremediação, corre-se o risco de favorecer a passagem de metal complexado para o lençol freático, antes que as plantas hiperacumuladoras de metais os absorvam (Wu et al., 2004). Embora seja uma molécula relativamente complexa, existem evidências de que possa sofrer biodegradação, o que poderia minimizar pelos menos em 
parte o risco. Chen et al. (2005) identificaram uma bactéria aeróbica, Burkholderia cepacia, que teve 91\% de eficiência em degradar o complexo Fe-EDTA.

\subsubsection{Torta de filtro}

Nas últimas décadas tem sido dada grande atenção à produção e ao uso na agricultura de resíduos urbanos e rurais, aliada a uma crescente preocupação com relação às conseqüências para o ambiente. Muitos materiais orgânicos como esterco de animal, compostos, tortas de oleaginosas, borras, torta de filtro, entre outros são depositados no solo para complementar sua fertilidade.

A torta de filtro é um resíduo proveniente do processo de clarificação do caldo extraído nas moendas, que consiste na retirada de sólidos em suspensão através da adição de uma suspensão de hidróxido de cálcio, que promove elevação de pH e a conseqüente floculação das substâncias coloidais. Com a posterior precipitação do material em suspensão, forma-se um lodo ou borra, que ainda contem quantidades consideráveis de sacarose a ser recuperada. Para dar consistência física apropriada para que se execute filtração ou prensagem da borra é necessário se adicionar a ela bagaço de cana moído e peneirado. Em suma, a torta de filtro consta essencialmente de bagaço de cana, ao qual forma incorporados compostos orgânicos do caldo de cana tais como: como pigmentos, proteínas, ceras, bem como fosfato de cálcio.

A composição da torta de filtro varia de acordo com: variedade e condição de maturação da cana, solo, compostos químicos adicionados ao processo de clarificação do caldo, entre outros. Dentre os nutrientes principais, nota-se uma predominância de cálcio, fósforo, mas pouco potássio (Glória, 1992), o que se explica pela diferença de solubilidade dos compostos formados por esses íons. O potássio passa incólume pelo processo de clarificação sendo encontrado posteriormente na vinhaça ou restilo, outro resíduo importante da indústria sucroalcooleira.

Os benefícios da aplicação de torta de filtro ao solo são amplamente reconhecidos. Rodella et al.(1990) mostraram que a torta de filtro aplicada em área total 
na dose de 100 t/ha promoveu uma expressiva alteração nas propriedades químicas do solo, como o aumento dos teores de fósforo, cálcio, carbono orgânico e CTC e a diminuição do alumínio trocável.

A torta de filtro é um resíduo orgânico muito valorizado na adubação da cultura da cana-de-açúcar. Para se ter uma idéia da importância do mesmo, considerem-se os valores citados por Rodella et al. (1990), que relacionou uma produção de 3,3 milhões de tonelada de torta de filtro à produção de 9 milhões de toneladas de açúcar. Mesmo produzido nesta grande proporção, o resíduo é em geral utilizado integralmente na adubação das próprias lavouras da unidade industrial que o produz.

Quando incorporada ao solo em grandes quantidades, a torta de filtro apresenta propriedades corretivas da acidez do solo, bem como leva até ele quantidades expressivas de Fe, Mn, Zn e Cu (Cerri et al., 1988). Com a utilização desse resíduo no solo, elevadas quantidades de macro e micronutrientes são adicionadas anualmente nas áreas próximas das unidades produtoras, podendo eventualmente com o passar do tempo elevar os teores desses elementos, que incluem alguns metais pesados (Ramalho, 1996). Entretanto, Ramalho \& Amaral Sobrinho (2001), analisando metais pesados aplicados ao solo pelo uso de resíduos agroindustriais verificaram que o uso da torta de filtro no solo Cambissolo, durante 20 anos acarretou aumentos significativos de teores totais de $\mathrm{Cd}, \mathrm{Pb}, \mathrm{Co}, \mathrm{Cr}, \mathrm{Cu}$ e Ni. Contudo, esses metais ocorriam em formas químicas pouco móveis e disponíveis para absorção pelas plantas.

\subsubsection{Esterco de Galinha}

O esterco animal é um fertilizante natural conhecido há muito tempo, sendo o um dos mais ricos em nutrientes essenciais. Usado em propriedades agrícolas em substituição parcial da adubação química, o esterco de galinha proporciona efeito benéfico na microbiota e estruturação e do solo, resultando em aumentos de 20 a $75 \%$ na produtividade de culturas, (Garcia et al.,1983; Colozzi Filho et al.,2000). Entende-se, portanto, a necessidade de estudos sobre a interação deste material com componentes do 
solo, já que ele, por ser um material orgânico, contribui para a complexação e adsorção de íons, alterando a biodisponibilidade dos mesmos (Wagemann,1980).

Quando aplicado ao solo, os materiais orgânicos podem contribuir para o complexo de cargas elétricas elevando a capacidade de troca catiônica (CTC) do mesmo. Nesse sentido, Rodella et al.(1995) observaram que a incorporação de esterco de galinha ao solo elevou a CTC de 13,2 para 37,9 mmol $\mathrm{kg}^{-1}$.Para a torta de filtro, os autores detectaram uma elevação para 23,1 mmol kg-1 . A elevação de CTC indica o material orgânico adicionado era ativo do ponto de vista químico e apto, portanto, para interagir com íons metálicos através de mecanismos de adsorção especifica ou não especifica.

Gimenez (1999) estudou a interação do cobre com esterco de aves, lodo aeróbico de esgoto doméstico e húmus comercial utilizado para jardinagem e observou que todos estes compostos atuam quer complexando ou adsorvendo de forma variável o metal, em função de suas diferentes composições químicas.

Alleoni et al. (2003) estudando a disponibilidade de cobre em função da matéria orgânica em dois solos com 522 e $475 \mathrm{mg} \mathrm{kg}^{-1}$ de Cu solúvel em DTPA pH 7,3, observaram que, apesar da incubação do solo com cama de frango aumentar o teor de carbono orgânico em ambos os casos, uma esperada redução nos teores de cobre não ocorreu. Observaram que os teores extraídos por $\mathrm{CaCl}_{2}$ aumentaram com aumento da dose de material orgânico. Os autores concluíram que esse comportamento pode ser explicado pela provável contribuição da cama de frango no fornecimento de cobre.

O esterco de galinha pode, em certos casos, causar preocupação como possível fonte de metais. Vanderwatt at al. (1994) trabalharam com um esterco apresentando 1196, 944, e $631 \mathrm{mg} \mathrm{kg}^{-1}$ de $\mathrm{Cu}, \mathrm{Mn}$, e $\mathrm{Zn}$, respectivamente, para determinar a disponibilidade desses metais a plantas de sorgo em experimento em casa de vegetação. Foi observada toxicidade apenas para manganês, mas em condições de campo, observaram acúmulo dos elementos citados em área que recebeu $6 \mathrm{Mg} \mathrm{ha}^{-1}$ de esterco durante 16 anos.

Miyazawa et al. (2002) estudaram a interação entre cobre, zinco e esterco de galinha adicionada ao solo e avaliaram a toxicidade desses elementos a plantas de feijão. Observaram um decréscimo de $20 \%$ na massa de matéria seca quando as concentrações 
de cobre e zinco no solo foram iguais ou superior a 1.0 e $2.0 \mathrm{mmol} \mathrm{kg}{ }^{-1}$, respectivamente. Para essas situações as concentrações na planta foram 13,4 mg kg-1 para cobre e 224,8 $\mathrm{mg} \mathrm{kg}^{-1}$ para zinco. A solução extratora de cobre do solo que possibilitou melhor correlação com a extração de metal pela planta foi o extrator Mehlich 1. 


\section{MATERIAL E MÉTODOS}

Para avaliar o comportamento do cobre aplicado ao solo através de calda bordalesa foram conduzidos ensaios em condições de laboratório, nos quais o fungicida foi aplicado ao solo acondicionado em colunas, bem como coletadas amostras de solo sob cultura de frutíferas.

\subsection{Mobilização do cobre aplicado pela calda bordalesa em colunas de solo}

O experimento foi conduzido em dois tipos de solo, sob condições de temperatura ambiente, no Laboratório de Físico-Química do Departamento de Ciências Exatas, Escola Superior de Agricultura “Luiz de Queiroz”/USP.

\subsubsection{Solos}

Foram considerados dois solos: Latossolo Vermelho eutroférrico (LVef) coletado em área cultivada com cana-de-açúcar no município de Santa Bárbara do Oeste e Latossolo Vermelho Amarelo distrófico típico (LVAd) coletado em área da Escola Superior de Agricultura “Luiz de Queiroz”, em Piracicaba, SP. As características físicas e químicas dos solos estudados são mostradas nas Tabelas 1 e 2, respectivamente. 
Tabela 1. Caracterização físicas dos solos utilizados nos experimentos

\begin{tabular}{|c|c|c|c|c|}
\hline \multirow{2}{*}{ Solo } & \multirow[t]{2}{*}{ Densidade } & \multicolumn{3}{|c|}{ Composição Granulométrica } \\
\hline & & Argila & Silte & Areia \\
\hline & $\mathrm{g} \mathrm{cm}^{-3}$ & \multicolumn{3}{|c|}{----------- \% ----------- } \\
\hline LVef & 1,06 & 67 & 13 & 20 \\
\hline LVAd & 1,19 & 22 & 8 & 70 \\
\hline
\end{tabular}

Os dois solos selecionados para o experimento podem ser considerados como perfeitamente adequados para representar duas condições contrastantes de granulométrica. Estas condições determinariam situações distintas de percolação da água de lixiviação que se planejava fazer passar pelo solo e assim detectar a mobilização do cobre por diferentes materiais orgânicos.

Tabela 2. Caracterização química dos solos empregados no experiemtos em colunas

\begin{tabular}{|c|c|c|c|c|c|c|c|c|c|c|c|c|}
\hline Solo & $\mathrm{pH}$ & M.O & $\mathrm{P}$ & K & Ca & $\mathrm{Mg}$ & $\mathrm{Al}$ & $\mathrm{H}+\mathrm{Al}$ & SB & CTC & V & $\mathrm{m}$ \\
\hline & $\mathrm{CaCl}_{2}$ & $\mathrm{~g} \mathrm{dm}^{-3}$ & $\mathrm{mg} \mathrm{dm}^{-3}$ & \multicolumn{7}{|c|}{-_- mmolc $\mathrm{kg}^{-1}$} & \multicolumn{2}{|c|}{-- \% -- } \\
\hline LVef & 5,5 & 18,6 & 11,6 & 15,9 & 22 & 9 & 1,0 & 39 & 46,9 & 85,9 & 54,6 & 2,1 \\
\hline LVAd & 4,7 & 15,8 & 3,7 & 1,1 & 13 & 5 & 2,7 & 31 & 19,1 & 50,1 & 38,1 & 12,4 \\
\hline
\end{tabular}

$\mathrm{SB}=$ soma de bases; $\mathrm{V}=$ saturação por bases; $\mathrm{m}=$ saturação por $\mathrm{Al}$; $\mathrm{CTC}=$ capacidade de troca de cátions a pH 7,0.

Com relação aos atributos químicos, entre os que se diferenciam ao confrontar os dois solos destacam-se: capacidade de troca de cátions, pH e saturação em bases, entre outros. Em termos gerais, evidencia-se o menor nível de fertilidade do solo LVAd.

\subsubsection{Montagem das colunas}

Como colunas de lixiviação foram utilizados dois segmentos de tubos de cloreto de polivinil (PVC) com 96 mm de diâmetro interno e $20 \mathrm{~cm}$ de altura, mantidos unidos por fita adesiva. O segmento inferior era fechado na sua parte inferior com tampa de PVC à qual se acoplou um tubo plástico, para auxiliar na coleta de solução percolada através da coluna (Figura 4). 


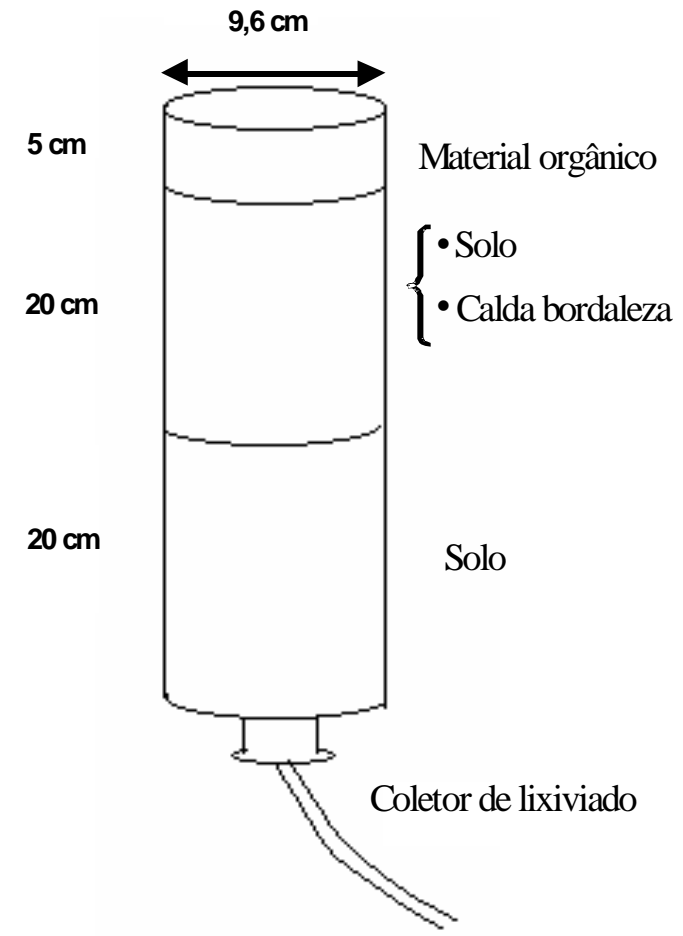

Figura 4 - Detalhes da coluna de lixiviação

Os segmentos inferiores de todas as colunas foram preenchidos com solo em sua condição natural, enquanto que os segmentos superiores foram preenchidos com o solo incubado com calda bordalesa. Pretendeu-se, desta forma representar o acúmulo do fungicida na camada superficial de um solo em condições de campo, ao longo de vários anos de utilização do produto.

Para incubação no solo, foi preparada calda com base no seguinte procedimento: $200 \mathrm{~g}$ de $\mathrm{CuSO}_{4} \cdot 5 \mathrm{H}_{2} \mathrm{O}$ foram dissolvidos em $20 \mathrm{~L}$ de água ligeiramente aquecida, aos quais se juntaram m $200 \mathrm{~g}$ de $\mathrm{CaO}$, ajustando-se o pH a 7,0 (Florestasite, 2003).

Foram aplicados $3.140 \mathrm{~mL}$ de calda bordalesa em $40 \mathrm{~kg}$ de solo LVef e de solo LVAd, quantidade de solo suficiente para preencher todos os segmentos superiores das colunas, e que corresponde a uma concentração de $200 \mathrm{mg} \mathrm{kg}^{-1}$ de cobre total no solo. Obteve-se assim, uma situação similar à contaminação da camada arável do solo em função de várias aplicações do produto, tomando-se como base os níveis de cobre, 
detectados no solo, decorrentes da aplicação da calda em condições de campo (Deluisa et al., 1996; Flores-Vélez, 1996).

Após incubação com a calda, homogeneizou-se bem o solo e deixando que ele secasse ao ar antes de ser usado para preencher o segmento superior das colunas.

\subsubsection{Aplicação dos tratamentos}

O cobre aplicado por um material alcalino como a calda bordalesa pressupõe que o elemento será relativamente imóvel no solo, mas que poderá ser mobilizado pela ação de compostos orgânicos que atuam como complexantes. Como fontes de compostos orgânicos foram selecionados os seguintes materiais: esterco de galinha, torta de filtro, $\mathrm{NaH}_{2}$ EDTA e citrato de amônio, incluído assim dois materiais orgânicos de uso generalizado na agricultura, um material sintético de elevado poder complexante, e um composto químico que pode representar os agentes quelantes de ocorrência natural no ambiente.

A adição desses materiais foi feita com o objetivo de fornecer ligantes orgânicos para a complexação do cobre e promover sua possível mobilização através da coluna de solo nas lixiviações previstas. Deste modo, estabelece-se um confronto entre o equilíbrio de dissolução dos compostos de cobre presentes na calda bordalesa e o equilíbrio de formação de complexos orgânicos.

Os tratamentos foram estabelecidos em 4 repetições, segundo esquema fatorial 2 x 5, combinando 2 solos e 4 adições de materiais orgânicos e uma testemunha. O delineamento estatístico foi inteiramente casualizado.

A torta de filtro e o esterco de galinha foram incorporados aos primeiros $5 \mathrm{~cm}$ do seguimento superior da coluna preenchido com solo tratado com calda bordalesa. A caracterização química desses materiais forneceu os resultados mostrados na Tabela 3, empregando métodos analíticos descritos em Brasil (1988) e Rodella \& Alcarde (1994).

A torta de filtro e o esterco de galinha foram aplicados em doses correspondentes a $10 \mathrm{t}_{\mathrm{de}} \mathrm{C}_{\mathrm{org}} \mathrm{ha}^{-1}$, o que correspondeu a 20,6 g de torta de filtro e 43,0 g 
de esterco de galinha para cada kg do solo LVef e 18,0 g de torta de filtro e 37,5 g de esterco de galinha para o solo LVAd. Uma vez incorporados aos solos das colunas, esses materiais orgânicos foram deixados incubar durante 60 dias, mantendo-se a umidade a $60 \%$ da capacidade de retenção total de água do solo.

Tabela 3. Resultados analíticos referentes aos materiais orgânicos estudados

\begin{tabular}{lccccccccc}
\hline Material orgânico & C org. & Mat. Org. & cinzas & $\mathrm{N}$ tot. & CTC/C & CTC & C/N & $\mathrm{Cu}$ & $\mathrm{Na}$ \\
\cline { 2 - 8 } & & $\mathrm{g} \mathrm{kg}^{-1}$ & & & mmol c $^{+} \mathrm{g}^{-1}$ & $\mathrm{mmol} \mathrm{c}^{+} \mathrm{kg}^{-1}$ & & $\mathrm{mg} \mathrm{kg}^{-1}$ & $\mathrm{gkg}^{-1}$ \\
Esterco de Galinha & 375 & 487 & 445 & 45 & 1,21 & 452 & 8,3 & 36 & 6,1 \\
Torta de Filtro & 180 & 691 & 252 & 35 & 2,94 & 528 & 5,1 & 62 & 0,3 \\
\hline
\end{tabular}

Os compostos citrato de amônio e o sal dissódico de EDTA não foram aplicados de uma única vez. Planejou-se a execução de 5 lixiviações com água nas colunas, espaçadas de 15 dias, para se avaliar a mobilização do cobre. Um dia antes dessas lixiviações eram aplicados às colunas pertinentes, $50 \mathrm{~mL}$ da solução $\mathrm{NaH}_{2}$ EDTA 0,01 mol L ${ }^{-1}$ e $50 \mathrm{~mL}$ da solução citrato de amônio 0,01 mol L ${ }^{-1}$. Assim esses compostos foram aplicados às colunas na quantidade total de $2,5 \mathrm{mmol}$, a qual corresponde a $80 \%$ da quantidade teoricamente necessária de EDTA para complexar completamente o cobre aplicado à coluna. As aplicações foram parceladas em função das recomendações de Thayalakumaran et al. (2003). A Figura 5 mostra a distribuição dos tratamentos para cada coluna, para ambos os solos utilizados.

\subsubsection{Coleta dos lixiviados}

Como mencionado anteriormente, no dia seguinte à aplicação das soluções eram efetuadas lixiviações em todas as colunas. Nesse processo, aplicou-se água destilada em volume suficiente para saturar o solo e possibilitar a coleta de cerca de 100 $\mathrm{mL}$ de lixiviado, sendo que volume exato foi avaliado por pesagem. O volume total de água aplicado à coluna não foi estabelecido para se relacionar com nenhum valor de 
precipitação pluviométrica; o objetivo era favorecer a movimentação do cobre através da coluna.

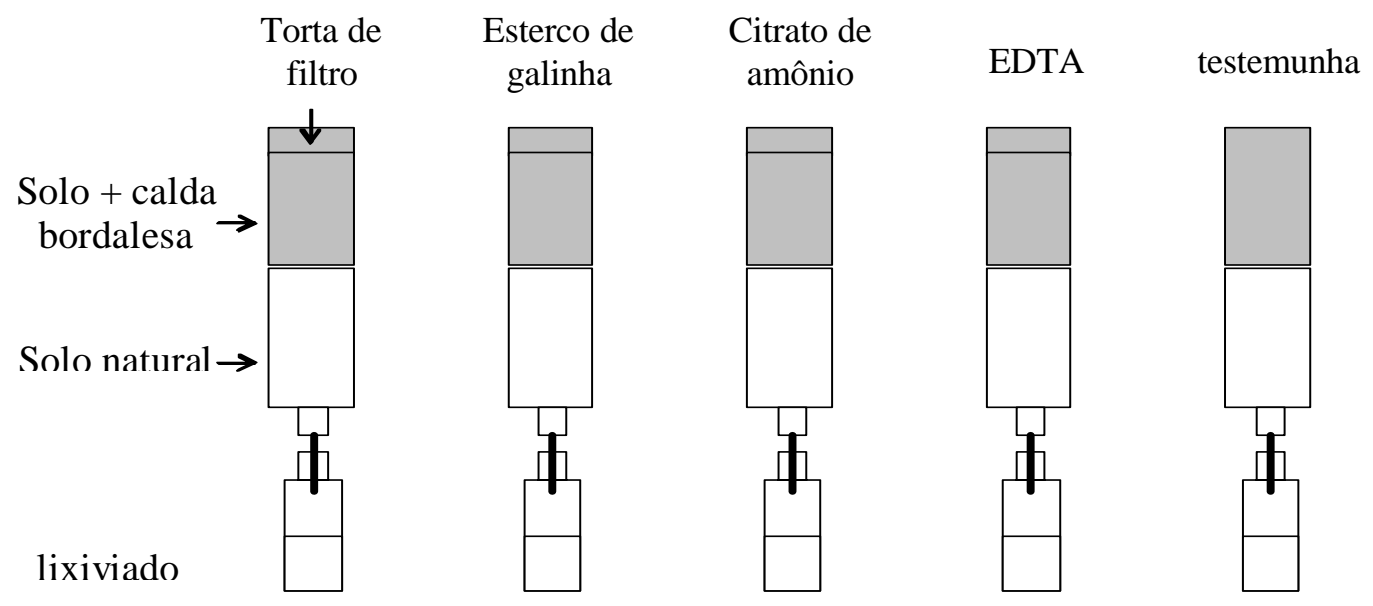

Figura 5 - Esquema da distribuição dos tratamentos por coluna

Logo após a coleta, os extratos lixiviados foram submetidos à determinação de $\mathrm{pH}$, condutividade elétrica e sódio. A determinação analítica do carbono foi feita por meio de oxidação com dicromato de potássio em meio ácido e posterior titulação com sulfato ferroso amoniacal, tal qual é feito para amostras de solo (Walkley \& Black, 1934). A determinação de cobre foi feita por espectroscopia de absorção atômica em chama ar-acetileno.

\subsubsection{Análise do solo contido nas colunas}

Após a condução das lixiviações deixou-se o solo secar parcialmente nas colunas de PVC antes de efetuar a desmontagem das mesmas. Foram então coletadas e armazenadas separadamente as massas de solo dos dois segmentos das colunas, com e sem calda bordalesa. 
Na determinação do teor de cobre solúvel foi empregada extração com DTPA (acido dietileno-triaminopentacético), conforme descrita por Amacher (1996). Foram pesados $10 \mathrm{~g}$ de terra seca ao ar, adicionando-se $20 \mathrm{~mL}$ da solução extratora DTPA-TEA a pH 7,3. Em seguida, a suspensão foi agitada por duas horas a 180 ciclos/min, para que o equilíbrio pudesse ser atingido. Depois disso, o material foi filtrado obtendo-se o extrato. A determinação de $\mathrm{Cu}$ no extrato foi efetuada por espectrometria de absorção atômica em chama de ar-acetileno.

Para a determinação de $\mathrm{Cu}$ total foi empregado o método EPA-3050 para determinação de metais da EPA, Environment Protection Agency, (United States, 2003), aquecendo-se próximo à ebulição por cerca de 15 minutos, 1 g de solo e $10 \mathrm{~mL}$ de $\mathrm{HNO}_{3}$ $(1+1)$ e, em seguida, aquecimento com adição de $5 \mathrm{~mL}$ de $\mathrm{HNO}_{3}$ concentrado. No extrato efetuou-se a determinação do Cu total por espectrometria de absorção atômica.

\subsection{Comportamento do cobre em alguns solos cultivados com frutíferas tratados com calda bordalesa}

Foram coletadas amostras de terra no município de Louveira (Latitude - S $23^{\circ}$ 5’; Longitude - W 46 56') no Estado de São Paulo, em áreas cultivadas por frutíferas nas quais se usa rotineiramente calda bordalesa como fungicida.

As amostras foram coletadas na profundidade de 0-20 cm em 8 propriedades, em pomares com Figo Roxo ou Uva Niágara, onde foi aplicada calda bordalesa num período de 2 a 10 anos (Quadro 2).

Deve ser salientado que este estudo envolveu uma área muito pequena de solos sob frutíferas do Estado de São Paulo e objetivou essencialmente levantar teores de cobre em solos sob aplicação rotineira da calda bordalesa e fornecer um termo de comparação aos valores obtidos no estudo conduzido em colunas. Os resultados das análises químicas dos solos coletados são mostrados na Tabela 4. 


\begin{tabular}{|clc|}
\hline Amostra & \multicolumn{1}{c}{ Cultura } & Tempo de aplicação (anos) \\
\hline 1 & Uvas Niágara & 2 \\
2 & Figo Roxo & 2 \\
3 & Uvas Niágara & 4 \\
4 & Figo Roxo & 7 \\
5 & Uvas Niágara & 7 \\
6 & Figo Roxo & 8 \\
7 & Figo Roxo & 10 \\
8 & Uvas Niágara & 10 \\
\hline
\end{tabular}

Quadro 2 - Cultura e tempo de aplicação de calda bordalesa em pomares onde foi amostrado solo no município de Louveira, São Paulo

De maneira geral, pode-se observar que os atributos químicos dos solos selecionados são essencialmente similares. Os pomares que tiveram o solo amostrado se localizam relativamente próximos uns ao outros, em uma região onde predomina o solo Argissolo Vermelho Amarelo distrófico (AVAd).

Tabela 4. Caracterização química dos solos sob cultivo de frutíferas

\begin{tabular}{|c|c|c|c|c|c|c|c|c|c|c|c|c|c|}
\hline Amostra & $\begin{array}{c}\mathrm{pH} \\
\mathrm{CaCl}^{2}\end{array}$ & $\begin{array}{r}\text { Corg } \\
\mathrm{gk} \\
\end{array}$ & $\mathrm{MO}$ & $\mathrm{P}$ & $\mathrm{H}+\mathrm{A}$ & $\mathrm{K}$ & $\begin{array}{c}\mathrm{Ca} \\
\mathrm{mmo}\end{array}$ & $\begin{array}{l}\mathrm{Mg} \\
\mathrm{lc} \mathrm{dn}\end{array}$ & $\mathrm{Al}$ & SB & СТС & $\mathrm{m}$ & V\% \\
\hline 1 & 6,8 & 14,1 & 24,2 & 295,2 & 10 & 3,7 & 125 & 33 & 0,7 & 161,7 & 171,7 & 0,4 & 94,2 \\
\hline 2 & 6,8 & 8,1 & 14,0 & 85,7 & 13 & 3,8 & 81 & 38 & 0,5 & 122,8 & 135,8 & 0,4 & 90,4 \\
\hline 3 & 6,0 & 14,6 & 25,1 & 288,0 & 24 & 6,0 & 90 & 21 & 0,7 & 117,0 & 141,0 & 0,6 & 83,0 \\
\hline 4 & 6,1 & 17,8 & 30,7 & 79,9 & 17 & 11,6 & 63 & 22 & 0,7 & 96,6 & 113,6 & 0,7 & 85,0 \\
\hline 5 & 5,6 & 12,4 & 21,4 & 14,8 & 24 & 3,0 & 36 & 15 & 0,6 & 54,0 & 78,0 & 1,1 & 69,2 \\
\hline 6 & 7,1 & 11,9 & 20,5 & 20,2 & 10 & 1,2 & 71 & 18 & 0,7 & 90,2 & 100,2 & 0,8 & 90,0 \\
\hline 7 & 6,1 & 15,7 & 27,0 & 248,4 & 20 & 3,3 & 99 & 13 & 0,8 & 115,3 & 135,3 & 0,7 & 85,2 \\
\hline 8 & 5,1 & 11,9 & 20,5 & 142,6 & 38 & 5,2 & 45 & 10 & 0,9 & 60,2 & 98,2 & 1,5 & 61,3 \\
\hline
\end{tabular}

SB = soma de bases; $\mathrm{V}$ = saturação por bases; $\mathrm{m}$ = saturação por alumínio; CTC = capacidade de troca de cátions a $\mathrm{pH} 7,0$.

\subsubsection{Análises de solo}

A análise química rotineira de solo para determinação de $\mathrm{pH}$, carbono orgânico, P, K, Ca, Mg, H+Al foram feitas de acordo Camargo et al. (1986). As determinações dos teores totais e disponíveis de cobre foram efetuadas conforme procedimentos descritos em 3.1.5. 


\subsubsection{Fracionamento do cobre}

O fracionamento foi utilizado para avaliar a distribuição do cobre nas frações dos solos sob frutíferas coletados no município de Louveira, onde foi aplicada a calda bordalesa. Com base nos resultados obtidos, é possível inferir sobre a biodisponibilidade do metal, uma vez que as frações do metal na fase sólida controlam, em parte, a sua presença na solução do solo (Candelária \& Chang, 1997).

O procedimento utilizado foi o descrito por Kabala e Singh (2001) por sua simplicidade e eficiência em evidenciar o comportamento do cobre, zinco e chumbo em áreas próximas a indústrias metalúrgicas. Foram consideradas as frações:

\section{F1: fração trocável + solúvel}

Foram pesados $2 \mathrm{~g}$ de solo seco ao ar e colocados num tubo de centrifuga de 50 mL. Foram então adicionados: $20 \mathrm{~mL}$ de acetato de amônio $1 \mathrm{~mol} \mathrm{~L}^{-1}$ a pH 7, agitandose por $2 \mathrm{~h}$ e centrifugando por $30 \mathrm{~min}$, lavando em seguida com $10 \mathrm{~mL}$ de água deionizada, centrifugando e combinando os sobrenadantes.

\section{F2: fração ligada aos carbonatos}

Extraída a partir do resíduo de F1, adicionando-se $20 \mathrm{~mL}$ de acetato de amônio $1 \mathrm{~mol} \mathrm{~L}^{-1}$ a $\mathrm{pH}$, agitando por $2 \mathrm{~h}$ e centrifugando por $30 \mathrm{~min}$, lavando com $10 \mathrm{~mL}$ de água deionizada, centrifugando e combinando os sobrenadantes.

F3: fração dos metais sorvidos ou oclusos principalmente nos óxidos de ferro e manganês

Extraído a partir do resíduo de do resíduo de F2, adicionando-se $20 \mathrm{~mL}$ de cloreto de hidroxilamina $0,04 \mathrm{~mol} \mathrm{~L}^{-1}$ em ácido acético $25 \%$, agitando por $6 \mathrm{~h}$ a $60^{\circ} \mathrm{C}$ em banho-maria, centrifugando por $30 \mathrm{~min}$, lavado com $10 \mathrm{~mL}$ de água deionizada, centrifugando e combinando os sobrenadantes. 


\section{F4: fração fortemente ligada à matéria orgânica}

Extraído a partir do resíduo de F3, adicionando-se 15 mL $\mathrm{H}_{2} \mathrm{O}_{2} 30 \%$ a $\mathrm{pH} 2$ (ajustado com $\mathrm{HNO}_{3}$ ) e agitando por $5,5 \mathrm{~h}$ a $80^{\circ} \mathrm{C}$ em banho-maria. Após resfriamento, acrescentou-se $5 \mathrm{~mL}$ de acetato de amônio 3,2 $\mathrm{mol} \mathrm{L}^{-1}$ em $\mathrm{HNO}_{3} 20 \%$, centrifugando-se por $30 \mathrm{~min}$, lavando com $10 \mathrm{~mL}$ de água deionizada, centrifugando e cominando os sobrenadantes.

\section{F5: fração residual.}

Foi pesado $1 \mathrm{~g}$ do resíduo do frasco F4 seco, e feita digestão com $10 \mathrm{~mL}$ de $\mathrm{HNO}_{3} 7 \mathrm{~mol} \mathrm{~L}^{-1}$ em chapa aquecedora por $6 \mathrm{~h}$. Após a evaporação, foram adicionados 1 $\mathrm{mL}$ de $\mathrm{HNO}_{3} 2 \mathrm{~mol} \mathrm{~L}^{-1}$. Ao final o volume foi completado a $50 \mathrm{~mL}$.

A concentração total de $\mathrm{Cu}$ no solo foi determinada em extratos obtidos por digestão com ácidos nítrico e perclórico a quente.

O cobre foi determinado em todos os extratos do procedimento de fracionamento por espectrometria de absorção atômica, em chama de ar acetileno. Todas as soluções padrões de calibração foram preparadas para apresenta composição similar a dos extratos.

\subsection{Avaliação da disponibilidade do cobre pelo Método de Neubauer modificado}

O experimento foi conduzido, segundo o procedimento descrito por Catani \& Bergamin (1961), em delineamento inteiramente casualizado, em 4 repetições no Laboratório do Departamento de Ciências Exatas, Escola Superior de Agricultura “Luiz de Queiroz”. Os tratamentos corresponderam às amostras de solos cultivados por frutíferas, bem como amostras dos solos LVef e LVAd retirados das colunas, incubados com calda bordalesa e submetidas à adição de materiais orgânicos $\mathrm{NaH}_{2} \mathrm{EDTA}$, citrato de amônio, torta de filtro e esterco de galinha.

Assim, foram misturados $20 \mathrm{~g}$ de terra com $40 \mathrm{~g}$ de areia lavada, em placas de Petri. Sobre a mistura, foram espalhadas $20 \mathrm{~g}$ de areia e plantadas 25 sementes de arroz 
variedade SCS 112 que, em seguida, foram cobertas com $10 \mathrm{~g}$ de areia. As sementes foram tratadas com o fungicida VBN para evitar o desenvolvimento de fungos que comprometem a germinação e o desenvolvimento das plantas. Cada placa recebeu 16 g de água. Um ensaio em branco foi preparado plantando-se 25 sementes em $60 \mathrm{~g}$ de areia, cobrindo-se as sementes com mais $10 \mathrm{~g}$ de areia, e molhando-as com $12 \mathrm{~g}$ de água.

As plantas foram colhidas 23 dias depois de germinadas e o material coletado foi submetido à digestão nitroperclórica e a determinação de $\mathrm{Cu}$ foi conduzida por absorção atômica em chama de ar-acetileno.

\subsection{Análise estatística}

Para as amostras procedentes do experimento em colunas, a análise de variância foi efetuada para o esquema fatorial 2 x 5, considerando as variáveis referentes à análise do lixiviado: $\mathrm{pH}$, condutividade elétrica, carbono orgânico, cobre e sódio. Considerou-se também variáveis da análise de solo dos segmentos superior e inferior das colunas: cobre extraído pelo DTPA e cobre total.

A análise de variância também foi efetuada para o ensaio Neubauer considerando-se as variáveis: cobre extraído pelas plântulas de arroz e concentração do elemento mesmo na planta.

As análises estatísticas foram realizadas com o auxílio do programa SANEST (Zonta \& Machado, 1991). 


\section{RESULTADOS E DISCUSSÃO}

Serão apresentados e discutidos os resultados do experimento de aplicação de calda bordalesa com dois solos em colunas de percolação, bem como resultados de experimentos com solos coletados em áreas sob culturas de uva e figo, onde calda bordalesa foi aplicada como defensivo.

\subsection{Mobilização do cobre aplicado pela calda bordalesa em colunas de solo}

O cobre na calda bordalesa está presente numa forma praticamente insolúvel e as lixiviações efetuadas representaram uma forma de acelerar a mobilização do elemento, por meio da passagem pela coluna de uma quantidade relativamente grande de água, avaliando o efeito de alguns materiais sobre este processo.

\subsubsection{Análise dos lixiviados}

As diferentes frações de lixiviado coletados foram analisadas quanto às determinações de pH e teores de cobre, sódio, carbono orgânico e condutividade elétrica, cujos resultados são apresentados na Tabela 5, como médias de quatro repetições.

Considerando os tratamentos em conjunto, os valores de $\mathrm{pH}$ do lixiviado refletiram o pH do solo, uma vez que o solo LVAd apresenta maior acidez que o LVef. Dentre os tratamentos, o efeito mais relevante sobre o $\mathrm{pH}$ foi do esterco de galinha no solo LVAd, que proporcionou um nítido abaixamento do pH do lixiviado. Esse efeito é 
decorrente do processo de nitrificação do nitrogênio amoniacal que é a forma predominante de nitrogênio no esterco de galinha.

Tabela 5. Caracterização do lixiviados obtidos nas colunas dos solos LVAd e LVef, onde foi aplicado cobre por meio de calda bordalesa (média de 4 repetições)

\begin{tabular}{|c|c|c|c|c|c|c|c|}
\hline \multirow[t]{2}{*}{ Tratamento } & $\mathrm{pH}$ & $\begin{array}{l}\text { Condutividade elétrica } \\
\mathrm{mS} \mathrm{cm}^{-1}\end{array}$ & $\begin{array}{l}\mathrm{Cu} \\
\mu \mathrm{g}\end{array}$ & \multicolumn{4}{|l|}{$\mathrm{C}_{\text {org }}$} \\
\hline & \multicolumn{7}{|c|}{ LVAd } \\
\hline Testemunha & $5,1 \mathrm{ab}$ & $1,9 \mathrm{c}$ & $6,2 \mathrm{~b}$ & 73,7 & b & 8,6 & b \\
\hline EDTA & $5,4 \mathrm{a}$ & $1,8 \mathrm{c}$ & 436,5 a & 93,9 & $\mathrm{a}$ & 11,3 & b \\
\hline Citrato & $5,3 \mathrm{a}$ & $1,9 \mathrm{c}$ & $4,6 \mathrm{~b}$ & 63,8 & b & 11,6 & b \\
\hline Torta de Filtro & $5,1 \mathrm{ab}$ & $3,1 \mathrm{~b}$ & $6,1 \mathrm{~b}$ & 38,2 & c & 8,7 & b \\
\hline Esterco de Galinha & $4,6 \mathrm{~b}$ & 5,2 a & $7,9 \mathrm{~b}$ & 39,2 & c & 156,2 & $\mathrm{a}$ \\
\hline & & & & & & & \\
\hline $\begin{array}{l}\text { Testemunha } \\
\text { EDTA }\end{array}$ & $6,3 \mathrm{ab}$ & $\begin{array}{ll}5,5 & b \\
5 & \end{array}$ & $\begin{array}{l}7,4 \mathrm{a} \\
87 \mathrm{a}\end{array}$ & $\begin{array}{l}33,3 \\
418\end{array}$ & & $\begin{array}{r}8,2 \\
190\end{array}$ & b \\
\hline Citrato & $6,6 \mathrm{a}$ & $6,2 \mathrm{~b}$ & $12,1 \mathrm{a}$ & 49,3 & & 5,9 & $\mathrm{~b}$ \\
\hline Torta de Filtro & $6,2 \mathrm{ab}$ & $6,0 \mathrm{~b}$ & 6,8 a & 51,2 & & 7,4 & $\mathrm{~b}$ \\
\hline Esterco de Galinha & $6,3 \mathrm{~b}$ & 8,1 a & 6,8 a & 44,9 & & 78,9 & $\mathrm{a}$ \\
\hline
\end{tabular}

Também a condutividade elétrica dos lixiviados coletados no solo LVef foi superior ao do solo LVAd, devido a menor concentração de nutrientes neste último solo, mais arenoso e de menor fertilidade. O efeito do esterco de galinha sobre a condutividade também pode ser atribuído ao aumento da concentração de íons $\mathrm{H}^{+}$, em decorrência do processo de nitrificação.

O elemento sódio foi determinado nos lixiviados com a intenção de acompanhar a movimentação do EDTA, uma vez que este agente complexante foi aplicado ao solo sob a forma de sal dissódico. Contudo, o elemento foi detectado em decorrência da aplicação do esterco de galinha o que foi inesperado, uma vez que os materiais orgânicos não tinham sido previamente analisados quanto à determinação deste íon. Na verdade, o sal $\mathrm{NaCl}$ pode ser misturado à ração para melhorar a palatabilidade ou ainda, aos dejetos das aves para controle de larvas, de modo que a presença do íon sódio não é justificada.

Vale observar também, que a massa de sódio deslocada da coluna através do lixiviado esteve em relação direta com o volume de água percolado pela coluna de solo 
(Figura 6), comportamento esse que está em acordo com a grande mobilidade deste elemento.

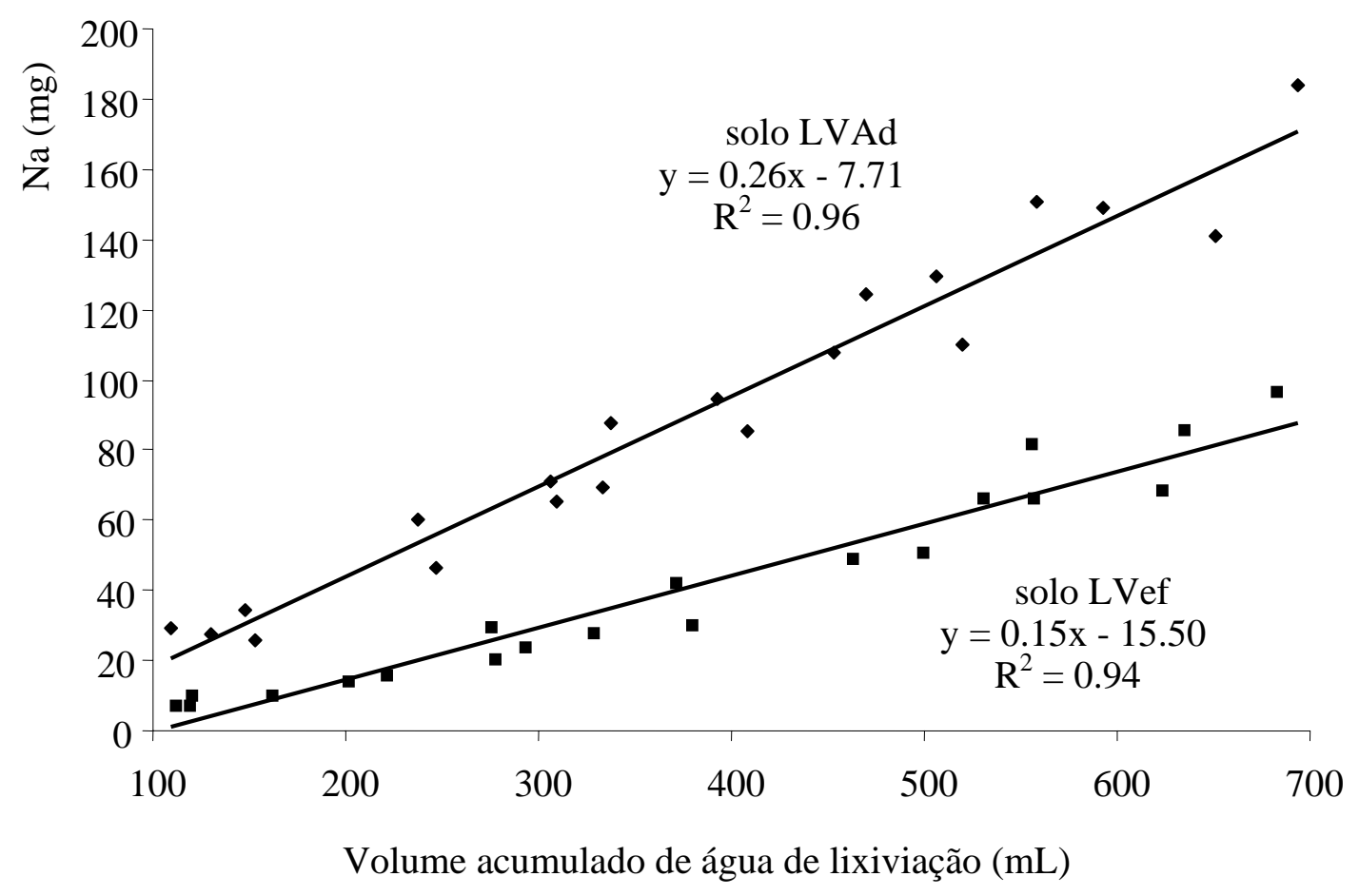

Figura 6 - Remoção acumulada de sódio dos solos LVAd e LVef em função da quantidade de água acumulada aplicada às colunas de solo tratado com esterco de galinha

Da quantidade total de sódio aplicada às colunas do solo LVAd, 228 mg, cerca de 68,5\% foi perdido nos lixiviados, enquanto que para o solo LVef essa proporção foi de 30,1\%. Esses valores, bem como os coeficientes angulares das equações da reta mostrados na Figura 6, servem como um indicativo de como cátions podem ser mais facilmente lixiviados no solo LVAd, conseqüência de seu menor valor de CTC.

O teor de carbono orgânico foi mais elevado nos lixiviados do tratamento com EDTA, mas esse efeito é difícil de ser explicado, pois, embora o EDTA seja um íon orgânico, não reage com o íon $\mathrm{Cr}_{2} \mathrm{O}_{7}^{-2}$ empregado na determinação de carbono orgânico. 
É provável que a aplicação do EDTA possa ter de algum modo influenciado a mobilização do carbono orgânico do próprio solo.

O efeito mais interessante detectado por meio da análise química dos lixiviados foi à mobilização de cobre pelo EDTA, observada apenas no solo LVAd. Conforme será discutido mais adiante, essa remoção de cobre no lixiviado da coluna do solo de textura arenosa correspondeu a uma fração muito pequena do cobre total aplicado ao solo por meio da calda bordalesa, entretanto, em comparação ao que foi removido nos demais tratamentos, aparece como um valor bastante significativo. Essa remoção através do lixiviado ocorreu em decorrência da forte complexão do EDTA e pelas condições químicas e físicas do solo LVAd, que permitiu o transporte do cobre complexado para fora da coluna. Essas condições de movimentação certamente não ocorreram no solo LVef.

Outro ponto interessante a ser discutido é que a remoção de cobre das colunas praticamente se completou logo nas primeiras etapas de lixiviação (Figura 7), quando da adição dos primeiros volumes de água empregados no estudo de lixiviação. Esse comportamento contrasta com a mobilização do íon $\mathrm{Na}^{+}$discutida anteriormente e pode ser explicado pela diferença de comportamento químico dos elementos citados no solo.

Fica evidente que o cobre aplicado ao solo não se mobiliza com facilidade, a não ser na presença de um agente complexante bastante eficiente como o EDTA. Na presença do íon citrato, ou sob aplicação de matéria orgânica através da torta de filtro e esterco de galinha, o cobre não foi detectado no lixiviado em quantidade superior à detectada na testemunha, onde a lixiviação foi efetuada apenas com água destilada. Pode-se especular que os ligantes orgânicos presentes nos materiais orgânicos não tinham afinidade suficiente para complexar o cobre ou foram afetados pelo $\mathrm{pH}$ do meio. De qualquer modo a analise é dificultada por não se saber a natureza exata desses possíveis agentes complexantes. 


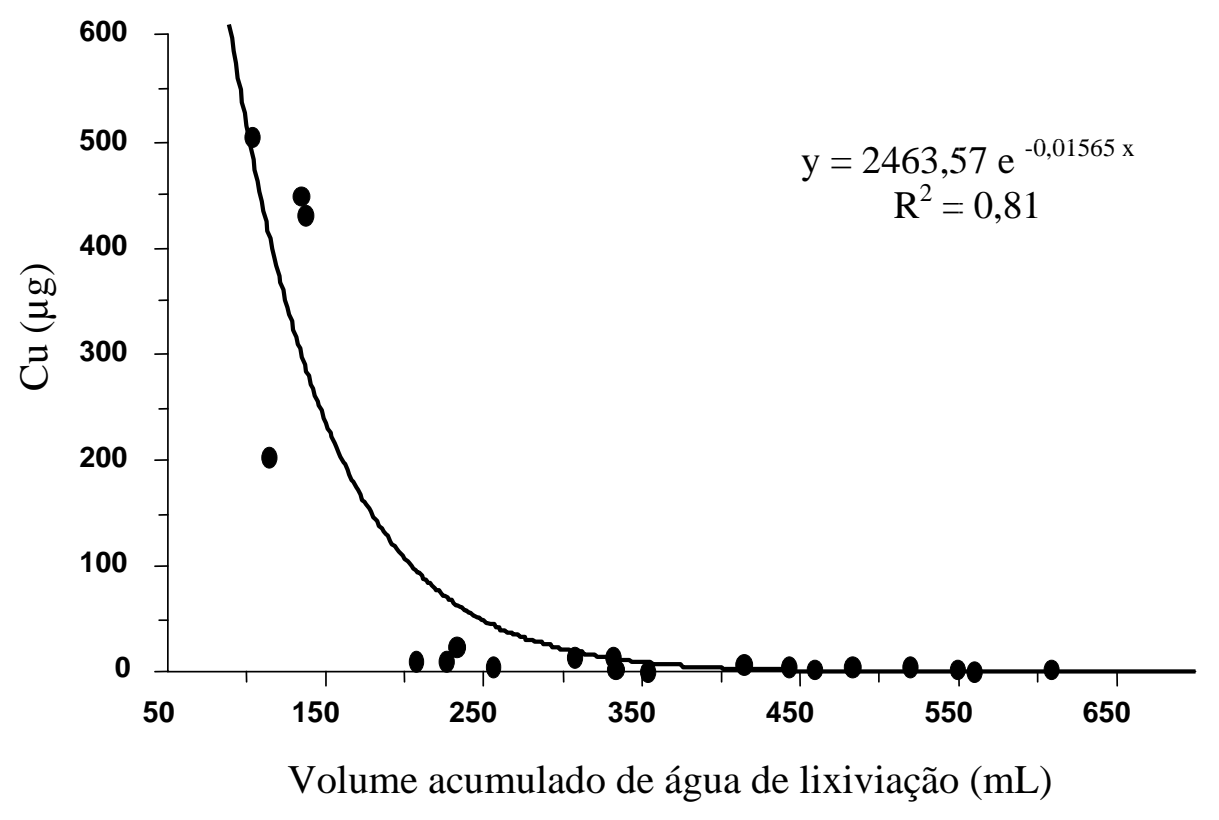

Figura 7 - Remoção de cobre do solo LVAd em função da quantidade de água acumulada aplicada às colunas onde foi aplicado EDTA

Fica evidente que o cobre aplicado ao solo não se mobiliza com facilidade, a não ser na presença de um agente complexante bastante eficiente como o EDTA. Na presença do íon citrato, ou sob aplicação de matéria orgânica através da torta de filtro e esterco de galinha, o cobre não foi detectado no lixiviado em quantidade superior à detectada na testemunha, onde a lixiviação foi efetuada apenas com água destilada. Pode-se especular que os ligantes orgânicos presentes nos materiais orgânicos não tinham afinidade suficiente para complexar o cobre ou foram afetados pelo $\mathrm{pH}$ do meio. De qualquer modo a analise é dificultada por não se saber a natureza exata desses possíveis agentes complexantes.

O íon citrato parece ter mostrado uma ligeira tendência de mobilizar cobre através do lixiviado no solo LVef. Contudo o aumento da concentração não foi significativo do ponto de vista estatístico.

Nas culturas de figo e uva são aplicadas sobre o solo grandes quantidades de materiais orgânicos como cobertura. Com o tempo uma fração importante desses 
materiais se decompõe e certamente possibilita a movimentação de compostos orgânicos solúveis através do perfil do solo. Tomando como base resultados da análise do lixiviado no presente estudo parece que o cobre aplicado pela calda bordalesa não tem translocação muito facilitada pela ação de compostos orgânicos produzidos na decomposição de resíduos orgânicos e esterco animal.

Já para o EDTA, a mobilização do cobre ocorreu, mesmo que em uma porcentagem reduzida e apenas no solo arenoso. A introdução de quelantes sintéticos no solo é uma possibilidade que não pode ser descartada uma vez que eles ocorrem em águas residuais industriais e urbanas e são relativamente estáveis.

\subsubsection{Análise do solo das colunas de lixiviação}

\subsubsection{1 pH $\left(\mathrm{H}_{2} \mathrm{O}\right)$}

Os valores de $\mathrm{pH}$ do solo ao final do experimento de lixiviação (Tabela 6) foram afetados com significância estatística pelos tratamentos estudados, sendo detectados os efeitos interativos duplos: solo e profundidade, bem como entre solo e materiais orgânicos e materiais orgânicos e profundidade. De maneira geral, independentemente da profundidade, no solo LVef não houve efeito significativo dos materiais orgânicos sobre o $\mathrm{pH}$ do solo, enquanto que no solo LVAd o $\mathrm{pH}$ foi significativamente menor quando se aplicou citrato. A aplicação de citrato tendeu a acidificar o solo, mas o solo LVef resistiu a esse efeito.

Tabela 6. $\mathrm{pH}\left(\mathrm{H}_{2} \mathrm{O}\right)$ dos solos contidos nas partes superior $(0-20 \mathrm{~cm})$ e inferior $(20-40$ $\mathrm{cm})$ das colunas

\begin{tabular}{lcccc}
\hline Tratamentos & \multicolumn{2}{c}{ LVAd } & \multicolumn{2}{c}{ LVef } \\
\hline & $0-20 \mathrm{~cm}$ & $20-40 \mathrm{~cm}$ & $0-20 \mathrm{~cm}$ & $20-40 \mathrm{~cm}$ \\
Testemunha & 6,25 & 4,84 & 6,52 & 5,66 \\
EDTA & 6,24 & 5,01 & 6,54 & 5,73 \\
Citrato & 5,72 & 4,87 & 6,21 & 5,84 \\
Torta & 6,15 & 4,87 & 6,42 & 5,61 \\
Esterco de galinha & 6,48 & 4,73 & 6,67 & 5,53 \\
\hline
\end{tabular}


A adição do íon citrato pode ter estimulado o desenvolvimento de microorganismo no solo. Em experimentos de incubação de solo onde a atividade microbiológica é mais intensa em geral são detectados menores valores de $\mathrm{pH}$ de solo no final do processo.

$\mathrm{O}$ pH do solo na camada de 20-40 cm foi menor que na camada de 0-20 cm nos dois solos, mas o abaixamento de $\mathrm{pH}$ no solo LVAd foi mais pronunciado. Assim a lixiviação causou acidificação no solo do segmento inferior das colunas, sendo que o solo LVAd foi mais afetado por esse processo por ter uma menor capacidade tampão.

Quanto ao efeito dos materiais adicionados ao solo, na camada de 0-20 cm observou-se que a aplicação de esterco de galinha resultou em $\mathrm{pH}$ significativamente maior que os demais, enquanto que a aplicação de citrato resultou no $\mathrm{pH}$ mais baixo. Entretanto, quando se considerou a camada de $20-40 \mathrm{~cm}$ da coluna a situação se inverteu. A explicação aqui é que o esterco de galinha apresenta amônia em sua composição, que sendo uma base causa, como seria de se esperar, a elevação imediata de pH. Contudo, a amônia sofre também nitrificação transformando-se em $\mathrm{NH}_{4}{ }^{+}$e nesse processo ocorre à produção de íons $\mathrm{H}^{+}$. Assim a lixiviação a adição de esterco de galinha causa a acidificação da camada inferior do solo, sendo que o próprio lixiviado do solo tratado com esse material apresentou igualmente o mais baixo $\mathrm{pH}$ conforme discutido anteriormente. Quanto à aplicação de citrato, seu efeito acidificante se restringiu ao segmento superior da coluna.

$\mathrm{O}$ pH do solo durante o transcorrer do experimento em coluna tem importância pois afeta a interação entre o íon $\mathrm{Cu}^{2+}$ e possíveis agentes complexantes. Assim, se materiais orgânicos adicionados ao solo causam abaixamento de $\mathrm{pH}$ em processo, evidentemente, não contribui para a formação de complexos por ligantes que eles próprios contem ou produzem. É provável que a interação de íon citrato em mobilizar o cobre possa ter como causa o abaixamento do $\mathrm{pH}$ que ele proporcionou. 


\subsubsection{Cobre}

Os resultados da análise química do solo contido das partes superior e inferior das colunas (Tabela 7) permitem constatar a movimentação do cobre através do solo sob a ação dos tratamentos. A analise estática revelou interação tripla com significância estatística entre: solo, profundidade e materiais orgânicos.

Tabela 7. Teores total e disponível de cobre nos solos LVAd e LVef contidos na parte superior e inferior das colunas onde foi aplicado cobre pela calda bordalesa (média de 4 repetições)

\begin{tabular}{|c|c|c|c|c|}
\hline \multirow{2}{*}{ Tratamento } & \multicolumn{2}{|c|}{$\mathrm{Cu}$ total } & \multicolumn{2}{|c|}{ Cu-DTPA } \\
\hline & Parte superior & Parte inferior & Parte superior & Parte inferior \\
\hline & \multicolumn{4}{|c|}{$\mathrm{mg} \mathrm{kg}^{-1}$} \\
\hline & \multicolumn{4}{|c|}{ Solo LVAd } \\
\hline Testemunha & 200,2 a & $2,8 \mathrm{~b}$ & 104.9 & $0,7 \mathrm{~b}$ \\
\hline EDTA & $175,0 \quad b$ & 26,8 a & 93.1 & 14,8 a \\
\hline Citrato & $192,8 \mathrm{ab}$ & 4,1 b & 96.3 & $2,1 \mathrm{~b}$ \\
\hline Torta de Filtro & $194,5 \mathrm{ab}$ & $4,8 \mathrm{~b}$ & 119,0 & $1,2 \mathrm{~b}$ \\
\hline \multirow[t]{2}{*}{ Esterco de Galinha } & 201,2 a & $3,8 \mathrm{~b}$ & 71.3 & $0,9 \mathrm{~b}$ \\
\hline & \multicolumn{4}{|c|}{ Solo LVef } \\
\hline Testemunha & 156,5 a & $5,2 \mathrm{~b}$ & 55,6 & $0,6 \mathrm{~b}$ \\
\hline EDTA & 165,8 a & 18,5 a & 70,7 & $5,7 \mathrm{a}$ \\
\hline Citrato & 164,5 a & $6,8 \mathrm{~b}$ & 68,7 & $2,2 \mathrm{ab}$ \\
\hline Torta de Filtro & 172,0 a & $6,8 \mathrm{~b}$ & 51,7 & $0,8 \mathrm{~b}$ \\
\hline Esterco de Galinha & 159,8 а & $8,2 \mathrm{~b}$ & 54,2 & $0,6 \mathrm{~b}$ \\
\hline
\end{tabular}

Conforme já observado na analise dos lixiviados, o EDTA aplicado ao solo LVAd interagiu com o cobre de modo mais evidente e os teores totais do elemento possibilitam verificar que uma fração significativa se translocou para o segmento inferior da coluna, ou seja, cerca de $25 \mathrm{mg} \mathrm{kg}^{-1}$ dos $200 \mathrm{mg} \mathrm{kg}^{-1} \mathrm{Cu}$ aplicados foram mobilizados do segmento superior para o inferior, quantidade essa que representa $12,5 \%$ do cobre aplicado.

Também no solo LVef uma fração relevante do cobre passou para o segmento inferior da coluna, mas essa movimentação parece não ter sido suficiente para que o cobre aparecesse em concentrações importantes nos lixiviados. 
Os teores de Cu extraídos pelo DTPA estão diretamente relacionados com os teores totais, sendo que no solo LVef a eficiência de extração foi menor.

Tabela 8. Massa de cobre mobilizada pelo lixiviados e presentes nos segmentos das colunas ao final do experimento em colunas

\begin{tabular}{|c|c|c|c|c|c|c|c|}
\hline \multirow[t]{2}{*}{ Tratamentos } & \multicolumn{2}{|c|}{ Lixiviado } & \multicolumn{2}{|c|}{ Segmento superior } & \multicolumn{2}{|c|}{ Segmento inferior } & \multirow{2}{*}{$\begin{array}{c}\text { Recup. }{ }^{* *} \text {. } \\
\%\end{array}$} \\
\hline & $\mu g *$ & $\%$ & $\mathrm{mg} *$ & $\%$ & $\mathrm{mg} *$ & $\%$ & \\
\hline & \multicolumn{7}{|c|}{ Solo LVAd } \\
\hline Testemunha & 6,1 & 0,0017 & 360,4 & 100,1 & 5,0 & 1,4 & 101,5 \\
\hline EDTA & 426,5 & 0,1185 & 315,0 & 87,5 & 48,2 & 13,4 & 100,9 \\
\hline Citrato & 4,6 & 0,0013 & 347,0 & 96,4 & 7,3 & 2,0 & 98,4 \\
\hline Torta de Filtro & 6,1 & 0,0017 & 350,1 & 97,3 & 8,6 & 2,4 & 99,7 \\
\hline \multirow[t]{2}{*}{ Esterco de Galinha } & 7,9 & 0,0022 & 362,2 & 100,6 & 6,8 & 1,9 & 102,5 \\
\hline & \multicolumn{7}{|c|}{ Solo LVef } \\
\hline Testemunha & 7,3 & 0,0023 & 250,4 & 78,3 & 8,3 & 2,6 & 80,9 \\
\hline EDTA & 8,7 & 0,0027 & 265,3 & 82,9 & 29,6 & 9,3 & 92,2 \\
\hline Citrato & 12,1 & 0,0038 & 263,2 & 82,3 & 10,9 & 3,4 & 85,7 \\
\hline Torta de Filtro & 6,8 & 0,0021 & 275,2 & 86,0 & 10,9 & 3,4 & 89,4 \\
\hline Esterco de Galinha & 6,8 & 0,0021 & 255,7 & 79,9 & 13,1 & 4,1 & 84,0 \\
\hline
\end{tabular}

O balanço de massa de cobre no experimento em colunas (Tabela 8) mostrou uma recuperação adequada da quantidade de cobre aplicado para o solo LVAd, arenoso, mas não para o solo LVef, argiloso. Essa diferença se justifica porque o teor de cobre determinado pelo método 3050 da EPA não pode ser considerado exatamente como total, pois a extração não é suficientemente enérgica. No solo LVef é provável que uma parte do cobre aplicado tenha interagido com os componentes do solo passando para uma forma mais fortemente ligada a ponto de não ser detectada na determinação e assim provocar um menor rendimento na extração do elemento.

Observa-se que, em geral, uma fração muito pequena do cobre aplicado, em torno de $0,002 \%$ foi mobilizada para fora das colunas de solo pelos lixiviados. A 
exceção foi observada na aplicação de EDTA no solo LVAd, quando 0,12 \% do cobre aplicado saiu da coluna, mas mesmo essa quantidade lixiviada poderia ser considerada inexpressiva. Uma questão interessante pode ser considerada. Se 13,4 \% do cobre aplicado passou para o segmento inferior da coluna, porque não foi detectada uma maior quantidade de cobre nos lixiviados? Foi percolada pelo solo uma quantidade relativamente grande de água, mas apenas nas primeiras porções é que uma quantidade expressiva de cobre foi detectada. De algum modo, o cobre mobilizado para a porção inferior da coluna, ainda que sob a forma de complexo com EDTA, parece ter sido retido por componentes do solo.

\subsection{Avaliação da disponibilidade do cobre pelo Método de Neubauer}

O emprego de extratores químicos para avaliação do teor de nutrientes disponível às plantas é um meio rápido e eficiente na rotina da avaliação de fertilidade dos solos agrícolas. Não deixa de ser verdade também, que é interessante se buscar uma validação do resultado obtido com uma solução extratora por meio da resposta de uma planta. Isso pode ser conseguido em ensaios de campo ou ensaio em vasos, meios que, freqüentemente, podem ser mais morosos que o desejado. O experimento de Neubauer contorna esse problema.

As avaliações podem ser feitas correlacionando-se teores de nutrientes no solo extraídos por diferentes meios com parâmetros como altura de plantas, massa vegetal seca produzida, concentração de nutriente e na planta e quantidade de nutriente extraída pela planta.

No presente estudo a técnica do experimento de Neubauer foi aplicada aos solos dos segmentos superiores das colunas do enxerimento de lixiviação bem como aos solos coletados no campo em pomares de figo e uva sob a aplicação de calda bordalesa. 


\subsubsection{Solos do experimento em coluna}

As medidas de massa seca da parte aérea (g), quantidade de Cu na planta (mg) e concentração de $\mathrm{Cu}$ das plantas de arroz crescidas nos solos provenientes dos segmentos superiores das colunas do enxerimento de lixiviação onde foi aplicado calda bordalesa são apresentados na Tabela 9.

Tabela 9. Massa seca, massa de cobre extraída e concentração de cobre na parte aérea de plantas de arroz cultivadas em experimento de Neubauer em solos LVAd e LVef onde foram aplicados $200 \mathrm{mg}$ de Cu por calda bordalesa

\begin{tabular}{|c|c|c|c|}
\hline Tratamento & $\begin{array}{c}\text { Massa seca da parte } \\
\text { aérea (g) }\end{array}$ & $\mathrm{Cu}(\mathrm{mg})$ & $\mathrm{Cu}\left(\mathrm{mg} \mathrm{kg}^{-1}\right)$ \\
\hline & & LVAd & \\
\hline Testemunha & $0,23 \quad \mathrm{a}$ & 8,45 b & 35,8 c \\
\hline EDTA & 0,21 a & 21,00 a & 100,3 a \\
\hline Citrato de amônio & 0,24 a & $9,40 \quad b$ & 39,1 bc \\
\hline Torta de Filtro & 0,25 a & $9,78 \mathrm{~b}$ & 39,2 bc \\
\hline \multirow[t]{2}{*}{ Esterco de Galinha } & $0,17 \quad b$ & $8,62 \mathrm{~b}$ & $51,0 \quad b$ \\
\hline & & Lvef & \\
\hline Testemunha & 0,23 a & $8,05 \mathrm{~b}$ & 35,4 \\
\hline EDTA & 0,23 a & $12,33 \quad \mathrm{a}$ & 53,6 \\
\hline Citrato de amônio & 0,22 a & 7,28 b & 33,6 \\
\hline Torta de Filtro & 0,23 a & $8,93 \mathrm{~b}$ & 38,9 \\
\hline Esterco de Galinha & $0,17 \quad b$ & $8,20 \quad b$ & 47,8 \\
\hline
\end{tabular}

Médias seguidas por letras distintas diferem entre si ao nível de 5 \% de significância pelo teste de Tukey.

As medidas de massa seca da parte aérea das plantas de arroz (Tabela 9) não refletiram de modo expressivo o efeito dos tratamentos. Portanto, neste caso, essa variável isoladamente não se configurou como um bom índice para ser relacionado com os teores de cobre no solo.

Isso é de se esperar, uma vez que no período de 23 dias as plântulas de arroz exploram completamente a pequena quantidade de solo colocada na placas de Petri e não têm condições de se desenvolverem plenamente. Cumpre ressaltar que, na verdade o 
objetivo do experimento não é proporcionar um grande desenvolvimento da parte área, mas sim uma intensiva exploração do solo pelas raízes.

O efeito do EDTA sobre o cobre aplicado ao solo pela calda bordalesa já foi demonstrado anteriormente na análise de lixiviados e também no experimento Neubauer ele aparece com destaque (Tabela 9). A diferença marcante, neste caso, é que a quantidade de cobre absorvida e a concentração de cobre nas plântulas de arroz demonstram o efeito do EDTA em ambos os solos estudados.

A aplicação do EDTA favoreceu claramente a absorção do cobre pelas plantas de arroz. Esse aumento de disponibilidade é de certo modo controverso, pois pressupõe a absorção do elemento sob a forma do complexo Cu-EDTA. Diversos autores debatem esse ponto, admitindo ou não a entrada de uma molécula relativamente grande de um complexo através das paredes celulares. As plantas podem atuar como receptores passivos de metais, pela interceptação e adsorção na raiz, mas por outro lado, as plantas modificam o pH da rizosfera e liberam agentes complexantes orgânicos, extraindo metais de complexos metálicos altamente estáveis (Tiffin, 1977).

\subsubsection{Solos coletados em áreas de frutíferas sob aplicação de calda bordalesa}

As medidas de massa seca da parte aérea (g), quantidade de Cu na planta (mg) e concentração de $\mathrm{Cu}$ das plantas de arroz crescidas nos solos provenientes dos pomares de frutíferas onde foi aplicado calda bordalesa são apresentados na Tabela 10.

Ao contrário do que foi discutido no item precedente, o experimento de Neubauer com solos coletados em pomares de frutíferas evidenciou que a absorção de cobre pelas plantas de arroz teve efeito negativo sobre a massa seca das mesmas (Figura 8), tanto quando se efetuaram correlações considerando a concentração de cobre no tecido vegetal $\left(\mathrm{R}^{2}=0,86\right)$ como quando se considerou a massa total de cobre absorvido $\left(R^{2}=0,63\right)$. 

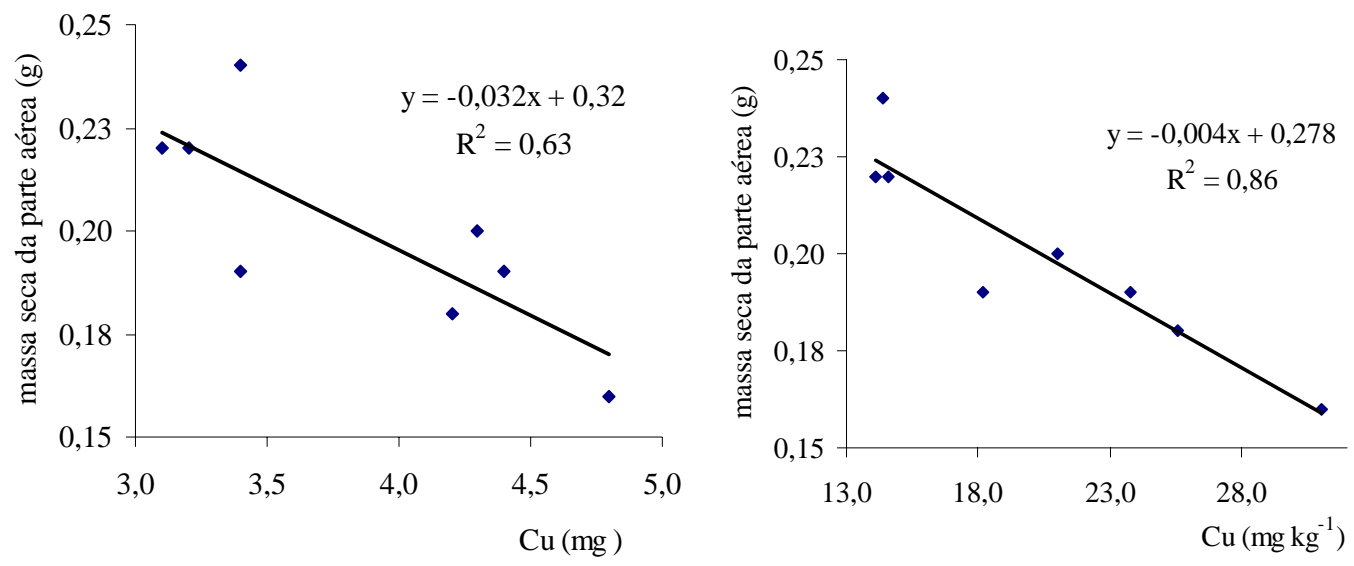

Figura 8 - Massa seca da parte aérea em função da massa de cobre $\mathrm{Cu}$ e concentração de $\mathrm{Cu}$ da planta

Tabela 10. Massa seca, massa de cobre extraída e concentração de cobre na parte aérea de plantas de arroz, cultivadas em experimento de Neubauer empregando solos sob cultivo de frutíferas e aplicação de calda bordalesa

\begin{tabular}{lcccc}
\hline \multicolumn{1}{c}{ Cultura } & $\begin{array}{c}\text { Tempo de } \\
\text { aplicação (anos) }\end{array}$ & $\begin{array}{c}\text { Massa seca } \\
\text { parte aérea }(\mathrm{g})\end{array}$ & $\begin{array}{c}\mathrm{Cu} \\
(\mathrm{mg})\end{array}$ & $\begin{array}{c}\mathrm{Cu} \\
\left(\mathrm{mg} \mathrm{kg}^{-1}\right)\end{array}$ \\
\hline Figo Roxo & 2 & $0,22 \mathrm{ab}$ & $3,2 \mathrm{~b}$ & $14,6 \mathrm{~cd}$ \\
Uvas Niágara & 2 & $0,24 \mathrm{a}$ & $3,4 \mathrm{ab}$ & $14,4 \mathrm{~cd}$ \\
Uvas Niágara & 4 & $0,19 \mathrm{bcd}$ & $3,4 \mathrm{ab}$ & $18,2 \mathrm{bc}$ \\
Figo Roxo & 7 & $0,18 \mathrm{bcd}$ & $4,2 \mathrm{ab}$ & $25,6 \mathrm{ab}$ \\
Uvas Niágara & 7 & $0,20 \mathrm{abc}$ & $4,3 \mathrm{ab}$ & $21,0 \mathrm{bc}$ \\
Figo Roxo & 8 & $0,16 \mathrm{~d}$ & $4,8 \mathrm{a}$ & $31,0 \mathrm{a}$ \\
Figo Roxo & 10 & $0,19 \mathrm{bcd}$ & $4,4 \mathrm{ab}$ & $23,8 \mathrm{abc}$ \\
Uvas Niágara & 10 & $0,22 \mathrm{ab}$ & $3,1 \mathrm{~b}$ & $14,1 \mathrm{~cd}$ \\
\hline \multicolumn{2}{l}{ Médias seguidas por letras distintas diferem entre si ao nível de $5 \%$ de significância pelo teste de Tukey. }
\end{tabular}

Esse efeito negativo pode ser até mesmo visualizado pelo desenvolvimento das plantas durante o transcorrer do experimento (Figura 9). Efeito semelhante foi observando por Bertoni et al. (2000) em plantas de arroz inundado tratadas com doses de sulfato de cobre pentahidratado (0; 0,75; 1,5; 2,25 e 3,0 mg Cu kg-1 de solo) para avaliar o efeito do cobre ao crescimento da planta. O efeito das doses de cobre teve efeito depressivo na produção da massa seca da parte aérea, que decresceu linearmente com as doses de cobre. 


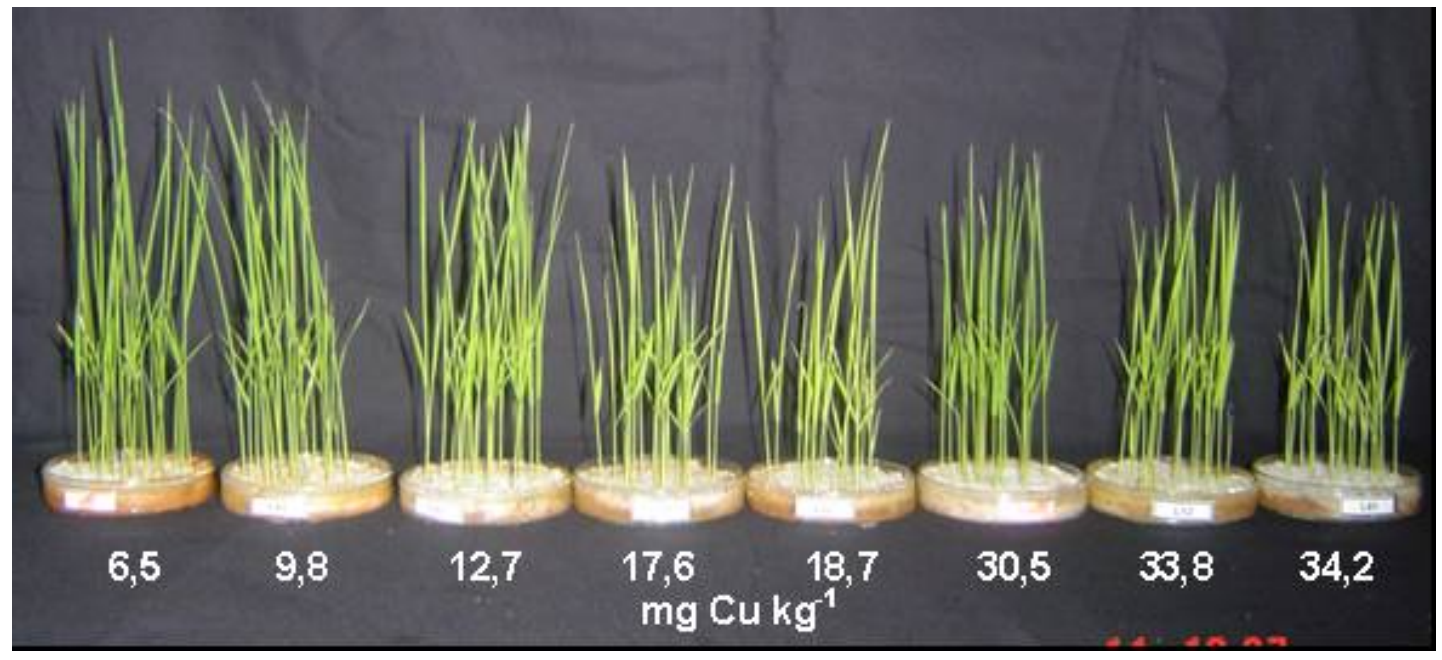

Figura 9 - Plantas de arroz aos 11 dias após a germinação contendo diferentes teores de cobre extraído pelo DTPA, indicados na figura

As quantidades de cobre absorvidas por vaso (mg $\mathrm{Cu}$ por vaso) e as concentrações de cobre nas plantas de arroz $\left(\mathrm{mg} \mathrm{Cu} \mathrm{kg}^{-1}\right.$ ) puderam ser relacionadas ao teor de $\mathrm{Cu}$ extraído dos solos pelo DTPA (Figura 10). Isso comprova que a solução extratora DTPA é adequada para avaliar a disponibilidade do cobre presente no solo em função da aplicação de calda bordalesa. Também no trabalho de Bertoni et al. (2000) constatou-se a eficiência do DTPA na predição da disponibilidade de cobre, confirmada pela correlação altamente significativa entre as concentrações de cobre nos solos pelo DTPA e as concentrações e acúmulo de cobre na parte aérea e massa seca da parte aérea das plantas de arroz cultivadas em três solos de várzea. Mesmo a massa seca da parte aérea não sendo um variável indicada para a seleção de métodos de extração de cobre, os autores obtiveram que o DTPA apresentou altos coeficientes de correlação com essa variável. 

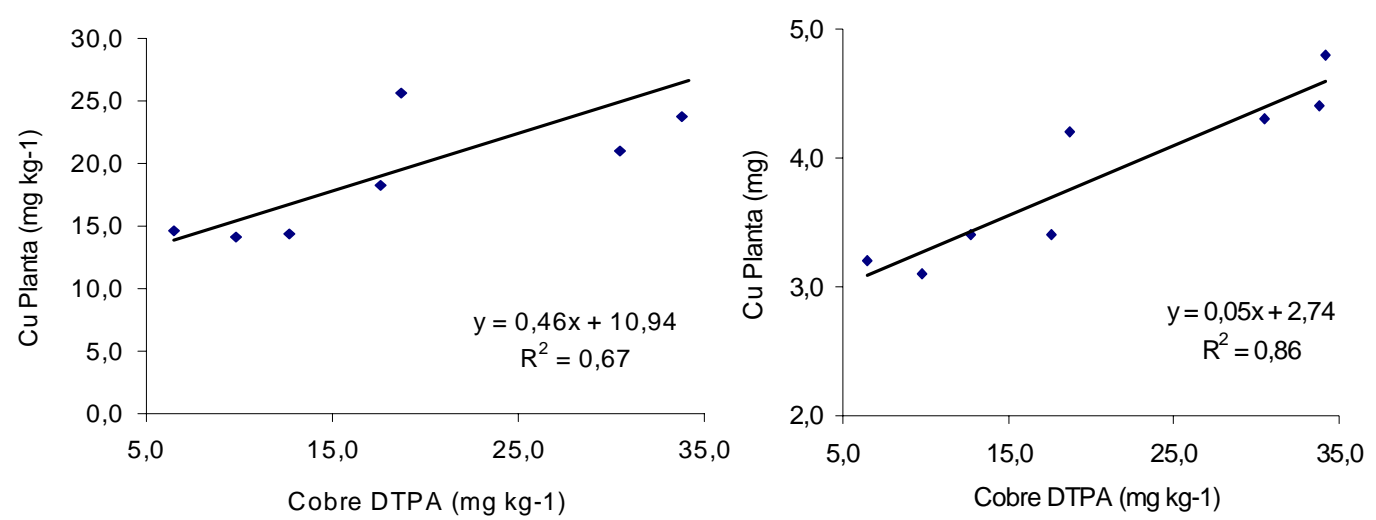

Figura 10 - Concentração e massa de cobre absorvida por plântulas de arroz em solos cultivados com frutíferas, em função do teor de cobre extraído por DTPA

\subsection{Comportamento do cobre em solos cultivados com frutíferas tratados com calda bordalesa}

A coleta de solos em áreas de exploração comercial de frutíferas foi efetuada para se ter uma noção da contaminação de solos pela calda bordalesa em condições reais de campo. Os fungicidas cúpricos podem causar o acumulo de cobre na camada superficial do solo e os teores atingidos podem ser suficiente mente elevados para causar toxicidade às plantas (Brun et al., 1998).

\subsubsection{Teores de Cu total do solo}

O cobre da calda bordalesa ocorre sob formas de baixa solubilidade e, assim, o teor de cobre total fornece uma boa indicação da contaminação da camada superficial do solo ao longo dos anos de aplicação do produto.

Os poucos locais amostrados no presente estudo não permitem uma análise mais profunda da contaminação dos solos da região de Louveira. Contudo, pode-se 
observar que os teores mais elevados de cobre total no solo, apresentados na Tabela 11, foram encontrados as áreas sob cultivo de uva.

Alloway (1995) aponta o intervalo de 60 a $125 \mathrm{mg} \mathrm{kg}^{-1} \mathrm{Cu}$ como sendo uma faixa crítica do teor total desse elemento no solo, ou seja, valores acima dos quais há possibilidade de toxicidade às plantas.

Tabela 11. Teores de cobre total e avaliado pelo extrator DTPA-TEA nas amostras de solos coletadas em áreas sob frutíferas

\begin{tabular}{lcrr}
\hline Cultura & $\begin{array}{c}\text { Tempo de aplicação } \\
\text { (anos) }\end{array}$ & $\begin{array}{r}\text { Cu total } \\
\mathrm{mg} \mathrm{kg}^{-1}\end{array}$ & $\begin{array}{c}\text { Cu-DTPA } \\
\mathrm{mg} \mathrm{kg}^{-1}\end{array}$ \\
\hline Figo Roxo & 2 & 40,8 & 6,5 \\
Uva Niágara & 2 & 44,8 & 12,7 \\
Uva Niágara & 4 & 96,6 & 17,6 \\
Figo Roxo & 7 & 65,3 & 18,7 \\
Uva Niágara & 7 & 108,8 & 30,5 \\
Figo Roxo & 8 & 80,1 & 34,2 \\
Figo Roxo & 10 & 78,4 & 33,8 \\
Uva Niágara & 10 & 47,7 & 9,8 \\
\hline
\end{tabular}

Uma comparação dos teores de cobre dos solos dos pomares com teores dos mesmos solos em áreas próximas não contaminadas não foi considerada adequada, uma vez que as culturas se localizavam em áreas de topografia acidentada, não sendo seguro escolher uma áreas contígua a elas livres da possibilidade de transporte de solo por erosão.

Marchiori Junior (2002) na região de Araraquara, em Latossolos cultivados com pomar de citros onde foram aplicados diversos agroquímicos, encontrou valores de cobre total variando de menos de 0,25 a 93,7 $\mathrm{mg} \mathrm{kg}^{-1}$. Alguns dos teores obtidos no presente estudo estiveram acima desse limite superior, o que seria justificado se a aplicação de cobre em frutíferas ocorrer com maior intensidade que na cultura de citros.

A faixa de concentração de cobre total de 41 a $109 \mathrm{mg} \mathrm{kg}^{-1}$ (Tabela 11), observada no presente trabalho, é em geral bastante inferior àquelas encontradas em estudos conduzidos em outras regiões do mundo. Assim, Flores Vélez et al. (1996) estudando solos ácidos franceses da região de Beuajolais determinou que o uso de calda 
bordalesa por mais de 100 anos resultou em uma acumulação significativa de cobre total no solo, que variou de 100 a $1500 \mathrm{mg} \mathrm{kg}^{-1}$. Por outro lado, Brun et al. (1998), para solos da região vinífera mediterrânea francesa, apresentou um intervalo de 31 a 250 mg kg-1 Cu total para áreas dos pomares, o qual contrasta fortemente com o intervalo obtido para áreas consideradas como testemunhas, fora dos mesmos, nas quais o teor do elemento variou de 14 a $29 \mathrm{mg} \mathrm{kg}^{-1}$.

Buscou-se correlacionar o teor de cobre total no solo com o período durante o qual a calda bordalesa foi aplicada às culturas, mas observou-se apenas para a cultura do figo uma tendência de maiores teores no solo com a idade do pomar (Figura 12).

\subsubsection{Teor cobre disponível do solo pelo DTPA}

O teor de cobre extraído pela solução DTPA é considerado como um bom indicador da fração desse nutriente disponível às plantas. Sabe-se que os micronutrientes de maneira geral passam, de um caráter de essencialidade para o de toxicidade num intervalo muito estreito em termos de concentração no solo.

Segundo Raij (1996) os teores de cobre do solo extraídos pelo DTPA e expressos em $\mathrm{mg} \mathrm{dm}^{-3} \mathrm{Cu}$ podem ser classificados como: baixo (0,0-0,2); médio (0,3$0,8)$; alto $(0,9-1,5)$, valores esse que servem de guia para recomendação de adubação com cobre para diferentes culturas no Estado de São Paulo. Adicionalmente, o intervalo 1,6 a $15 \mathrm{mg} \mathrm{dm}^{-3} \mathrm{Cu}$ poderia ser classificado como muito alto.

Esses teores, contudo, são estabelecidos basicamente para subsidiar recomendações de adubação com cobre e os teores classificados como alto ou muito alto não tem conotação de efeito tóxico, mas de não necessidade de aplicação do micronutriente. De qualquer modo, é necessário ser cauteloso na interpretação de resultados de determinação de micronutrientes no solo, pois, considerando-se as curvas de respostas de plantas a esses elementos observa-se que, em geral, pouco além das concentrações consideradas como suficientes ou da região onde a planta não mais responde, pode ter início abruptamente a região de toxicidade. 
Não são disponíveis na literatura indicações de teores de cobre extraídos pelo DTPA que representem toxicidade. Como um possível termo de comparação, pode ser citado o intervalo 50 a $100 \mathrm{mg} \mathrm{dm}^{-3}$ de Cu, extraído pela solução 0,05 mol L ${ }^{-1}$ EDTA e ácido acético 0,05 mol L'-1, proposto por MacNicol \& Beckett (1985).

Os teores de $\mathrm{Cu}$ disponível avaliados pelo extrator DTPA nas amostras dos solos cultivados sob frutíferas sob aplicação de calda bordalesa variaram na faixa de 6,5 a 34,2 $\mathrm{mg} \mathrm{kg}^{-1} \mathrm{Cu}$ (Tabela 11). Esses valores foram maiores que aqueles encontrados por Marchiori Junior (2002) pelo mesmo extrator em Latossolo sob cultivo de citros, os quais variaram entre 0,16 a $13 \mathrm{mg} \mathrm{kg}^{-1}$ de $\mathrm{Cu}$. Por outro lado, em solos cultivados com uva por mais de 15 anos na região da Serra no Rio Grande do Sul, foram detectados teores de cobre pelo DTPA muito mais elevados, 522 e $475 \mathrm{mg} \mathrm{kg}^{-1}$ de Cu (Alleoni et al., 2003).

Os teores de $\mathrm{Cu}$ total e Cu-DTPA nos solos em estudo foram correlacionados, verificando-se que, eliminando o valor de duas amostras de maior teor total, obteve-se um coeficiente determinação $\left(\mathrm{R}^{2}\right)$ igual a 0,95 (Figura 11). Desta forma, a disponibilidade do $\mathrm{Cu}$ para a solução do solo poderia ser inferida a partir da quantidade total de $\mathrm{Cu}$ presente no solo. È provável que para as duas amostras excluídas da correlação o teor de cobre total incluísse formas de cobre que não ocorreram nos outros locais considerados. Resultado similar foi obtido por Brun et al. (1998) em estudo com 29 amostras de solos cultivados com videiras no Sul da França, obtendo para $\mathrm{Cu}$ extraído por DTPA um coeficiente de correlação de 0,93 entre teores Cu-total e CuDTPA. 


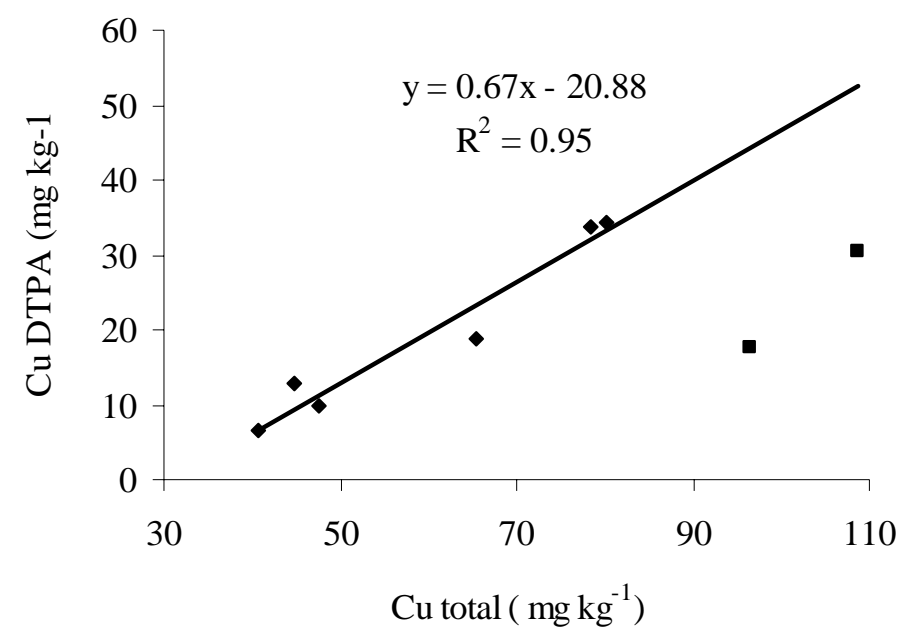

Figura 11 - Cobre extraído por DTPA relacionado ao Cu total na camada arável de solos de pomares cultivados com uva e figo, tratados com calda bordalesa

Conforme mencionada anteriormente, a relação entre tempo de uso de de calda bordalesa nos pomares de figo e uva e teores de cobre no solo não era manifestados de forma clara. Contudo, considerando apenas a cultura do figo, observou-se alta correlação entre tempo de aplicação do fungicida e concentração de Cu total e Cu-DTPA no solo (Figura 12).

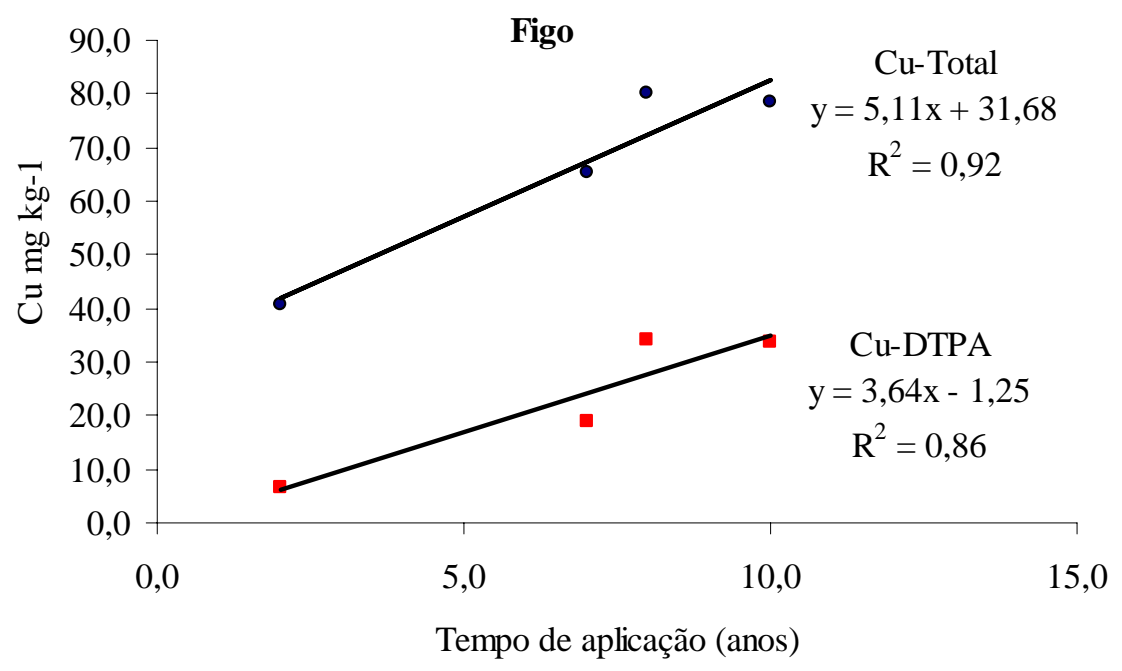

Figura 12 - Cobre extraído por DTPA e Cobre Total na camada arável de solo de pomares de uva (a) e figo (b) em função da idade se aplica calda bordalesa sob as culturas 
O acumulo de $\mathrm{Cu}$ na camada arável do solo, devido ao uso intensivo de fungicidas aplicados aos pomares vinícolas, é destacado em trabalhos tais como Flores Vélez et al. (1996), Deluisa et al. (1996) e Alleoni et al. (2003).

\subsubsection{Fracionamento do cobre em amostras de solos de pomares de figo e uva}

O fracionamento de metais é efetuado basicamente para se avaliar o destino do elemento adicionado ao solo entre seus vários compartimentos, os quais se caracterizam por diferentes graus de interação com o metal. Essa informação permite ter uma idéia do comportamento do metal e sua possível entrada nas plantas e movimentação no perfil do solo.

Quando metais são adicionados ao solo sob a forma solúvel podem se distribuir de maneira mais imediata nas frações trocável e ligada à matéria orgânica. A calda bordalesa contém cobre na forma de hidróxido de solubilidade baixa que pode permanecer no solo nessa condição por um período de tempo relativamente longo. Ligantes com alta afinidade pelo elemento, como o EDTA por exemplo, podem sobrepujar essa tendência à insolubilidade, como foi observado no estudo de lixiviação incluído no presente trabalho, contudo, a mobilização do cobre vai depender do confronto entre a afinidade do ligante presente no meio para com o cobre e a tendência do elemento em permanecer insolúvel.

As amostras de solo coletadas em pomares de figo e uva tratados com calda bordalesa foram submetidas ao fracionamento do cobre, ficando evidente na maioria dos locais amostrados a predominância do elemento sob formas fortemente ligadas, nas frações: residual, ligada a óxidos e ligada à matéria orgânica (Figura 13). Nogueirol et al. (2004) encontraram teores de Cu ligado à matéria orgânica entre 70 a 80\% e associado a óxidos representado entre 7 a 20\%, em solos de cultivados com vinhedos por mais de 15 anos, onde era aplicado fungicida cúprico.

De maneira geral, pode se constatar que o estudo fracionamento confirmou a expectativas em relação ao comportamento do cobre aplicado pela calda bordalesa. 
A fração residual, de maneira geral, não possibilita maiores inferências sobre o comportamento do elemento, visto que representa o elemento que não foi mobilizado nas frações precedentes, estas sim com caracterizações mais especificas em relação às ligações do metal com componentes do solo.

A afinidade do cobre em relação à matéria orgânica é bastante conhecida. Cobre adicionado ao solo na forma solúvel rapidamente deixa de ser mobilizado por extratores suaves, como solução de $\mathrm{CaCl}_{2}$, à medida que o teor de carbono orgânico no solo aumenta.

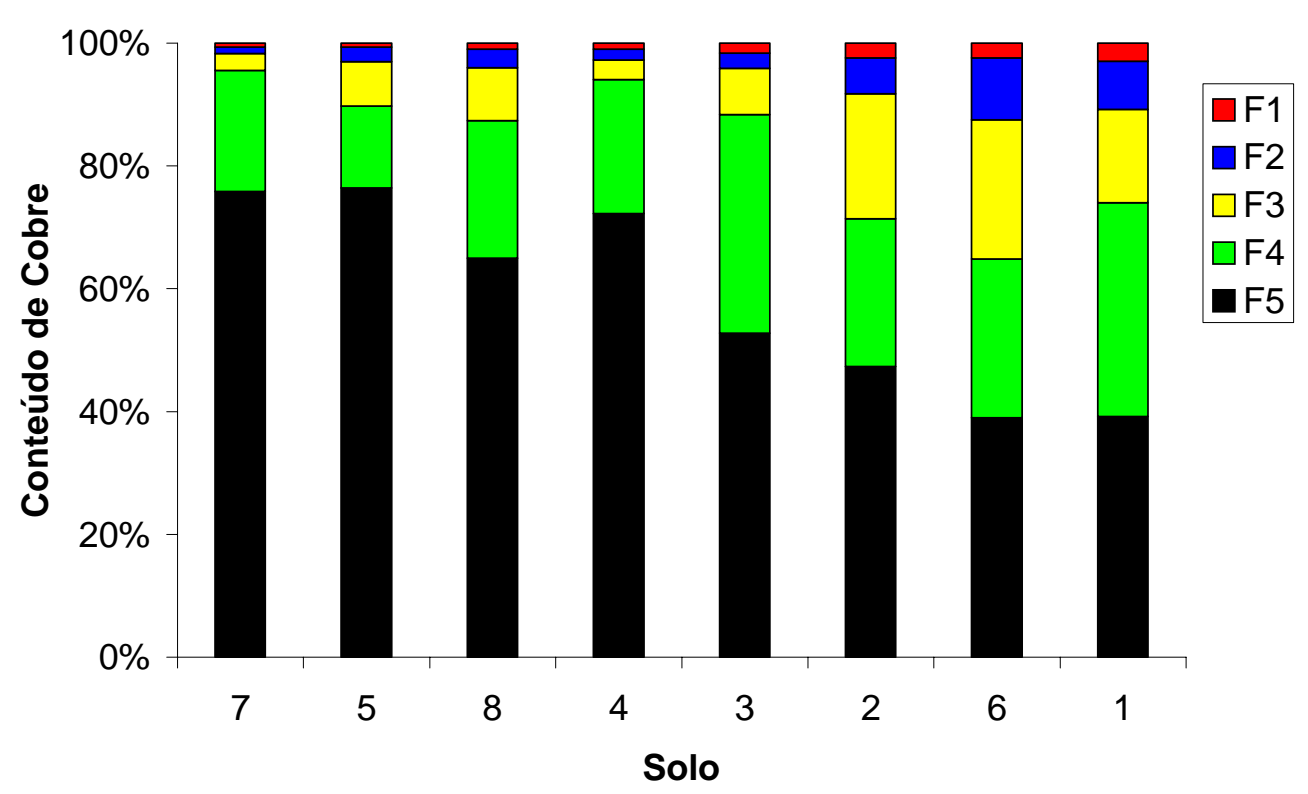

Figura 13 - Fracionamento de cobre em solos sob aplicação de calda bordalesa de 2 a 10 anos. F1 (solúvel + trocável), $\mathrm{NH}_{4} \mathrm{OAc} 1 \mathrm{M}, \mathrm{pH} 7,0 ; \mathrm{F} 2$ (carbonatos), $\mathrm{NH}_{4} \mathrm{OAc} 1 \mathrm{M}, \mathrm{pH} 5,0$; F3 (óxidos), $\mathrm{NH}_{4} \mathrm{OH} . \mathrm{HCl} 1 \mathrm{M}$ em HOAc 25\%, pH 7,0; F4 (mat.org), $\mathrm{H}_{2} \mathrm{O}_{2} 30 \%$ em $\mathrm{HNO}_{3}$, pH 2,0; F5 (residual), $\mathrm{HNO}_{3}$

No presente estudo foi possível correlacionar teores de cobre referentes a algumas frações com a extração de cobre pelo método de Neubauer. As frações residuais e ligadas à matéria orgânica apresentaram baixos coeficientes de determinação, mas para as demais frações os coeficientes de determinação foram elevados (Figura 14). 

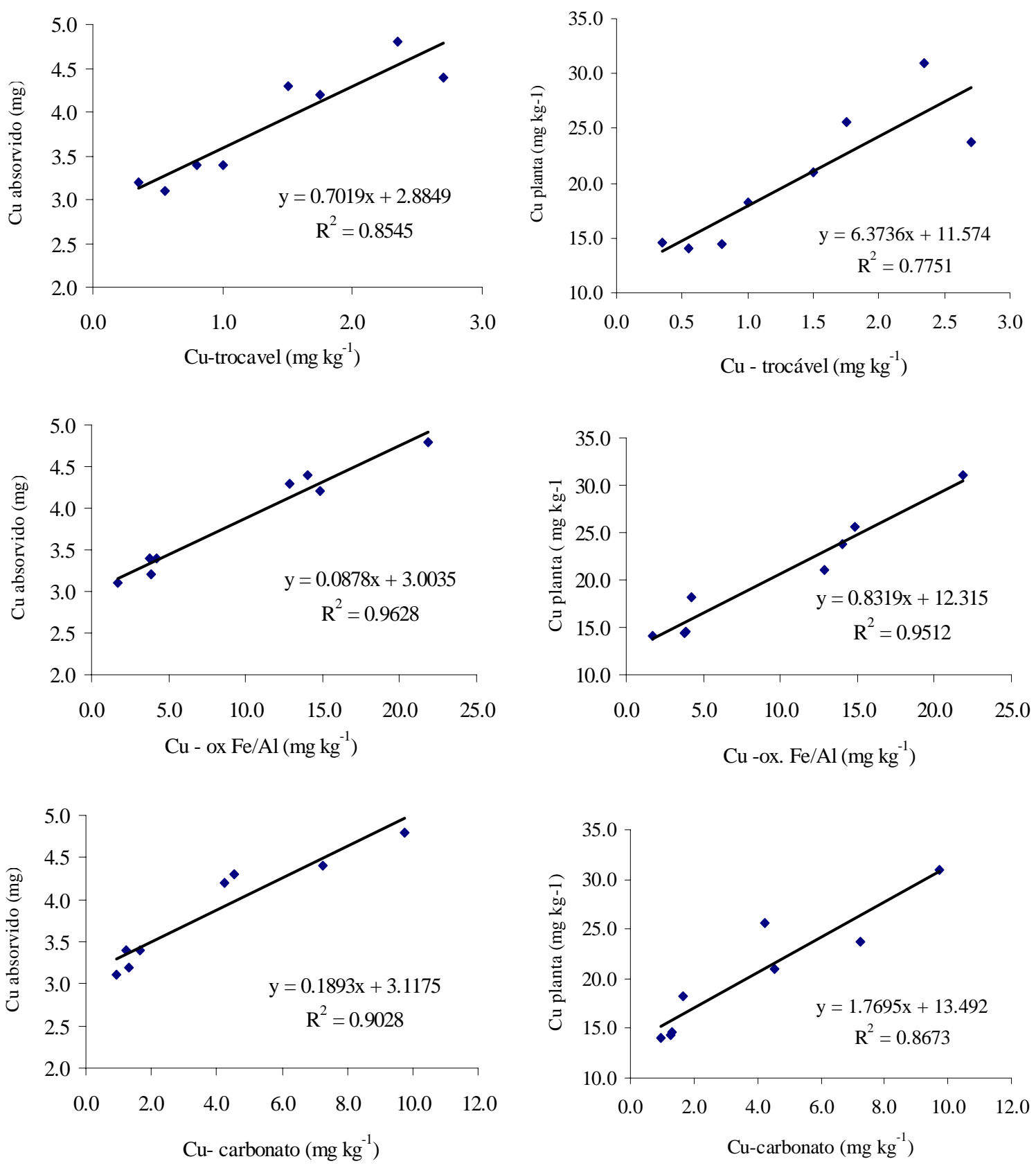

Figura 14 - Relações entre concentração de cobre na planta e massa de cobre extraído pela planta e o teor de cobre presente nas frações: trocável; ligada a óxidos de Fe e Mn e ligada a carbonato

Foi de certo modo surpreendente, a correlação entre as variáveis ligadas à planta com o teor de cobre ligado aos óxidos de ferro e manganês, que parece ser uma 
forma de ocorrência de metal pouco disponível as plantas. No entanto o mais altos coeficientes de determinação foram obtidos justamente para esta forma de ocorrência do cobre no solo.

Também foi possível correlacionar teores de cobre relativos a algumas frações trocáveis com o teor de cobre total. O valor de cobre extraível pelo acetato de amônio representou apenas 5,57\% do cobre total do solo, visto que o $\mathrm{Cu}$ proveniente da calda bordalesa é insolúvel e não forma complexos estáveis, já que grande parte do $\mathrm{Cu}$ disponível ocorre em forma quelatadas, o que dificulta a extração com um sal. Ao contrário, 64,49\% do cobre total é extraído pelo DTPA devido a sua capacidade em forma complexo com o cobre.

Outra informação interessante que se pôde obter a partir das determinações de teores totais de cobre no solo é que o método 3050 da EPA (UNITED STATES, 2003) se correlacionou perfeitamente com os valores obtidos pela digestão com ácidos nítrico e perclórico (Figura 15). Assim um método de digestão mais simples e rápido, rotineiramente empregado nos laboratórios agronômicos, pode ser utilizado quando da análise de solo em áreas sob aplicação de calda bordalesa, para a determinação do teor total de cobre.

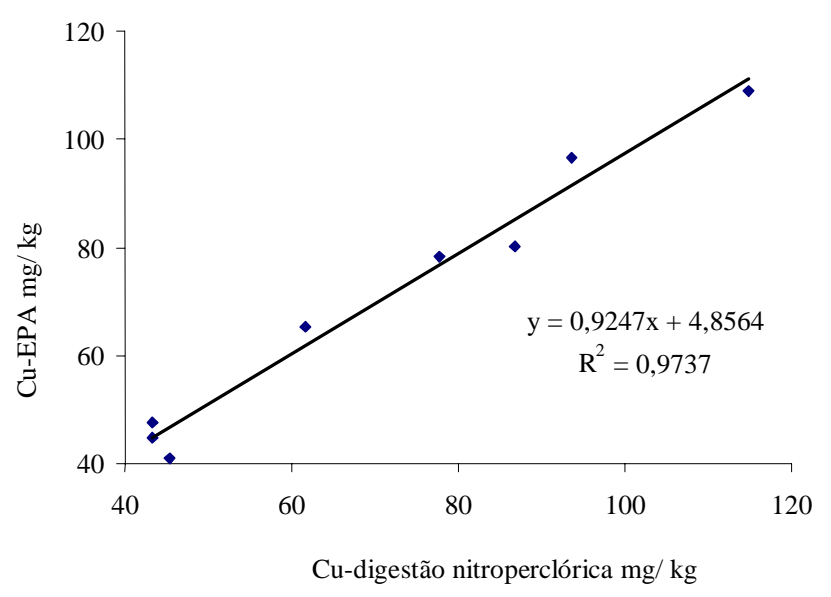

Figura 15 - Relação entre teores de cobre total eo solos contaminados com calda bordalesa determinados a partir de dois extratos: EPA 5030 e digestão nítrico perclórico 


\section{CONCLUSÕES}

- Sob lixiviação intensa com água, o EDTA proporcionou uma pequena mobilização do cobre contido na calda bordalesa em de colunas de solo de textura arenosa. Esterco de galinha, torta de filtro e citrato de amônio não tiveram nenhum efeito nesse sentido.

- O EDTA promoveu uma movimentação de cobre da parte superior para a parte inferior de colunas de solo submetidas a lixiviação com água, tanto para solo de textura arenosa como argilosa.

- Solos de áreas cultivadas com figo onde se aplica calda bordalesa apresentaram teores de cobre total e cobre extraído do solo por DTPA proporcionais ao tempo de uso do fungicida.

- A solução extratora de DTPA se mostrou eficiente em predizer a disponibilidade de cobre as plantas, conforme ficou evidenciado por meio de em experimentos de Neubauer. 


\section{REFERÊNCIAS BIBLIOGRÁFICAS}

ABREU, C.A. de; FERREIRA, M.E.; BORKERT, C.M. Disponibilidade e avaliação de elementos catiônicos: zinco e cobre. In: FERREIRA, M.E.; CRUZ, M.C.P. da; RAIJ, B.V.; ABREU, C.A. de. (Ed.). Micronutrientes e elementos tóxicos na agricultura. Jaboticabal: CNPq; FAPESP; POTAFOS, 2001. p.125-150.

AHUMADA, I.; MENDOZA, J.; ESCUDERO, P.; ASCAR, L. Effect of acetate, citrate, and lactate incorporation on distribution of cadmium and copper chemical forms in soil. Communications in Soil Science and Plant Analysis, v.32, n.5/6, p 771-785, 2001.

ALCARDE, J.C.; PONCHIO, C.O. A ação solubilizante das soluções de citrato de amônio e de ácido cítrico sobre fertilizantes fosfotados. Revista Brasileira de Ciência do Solo, v.3, p.173-178, 1979.

ALCARDE, J.C.; VALE, F. Solubilidade de micronutrientes contidos em formulações de fertilizantes, em extratores químicos. Revista Brasileira de Ciência do Solo, v.27, n.2, p.363-372, 2003.

ALLEONI, L.R.F.; NACHTIGALL, G.R.; CAMBRI, M.A.; NOGUEIROL, R.C.; LOPES, C.M. Disponibilidade de cobre em solos de vinhedos após aplicação de calda bordaleza por vários anos. (compact disc). In: CONGRESSO BRASILEIRO DE CIENCIA DO SOLO. 29, Ribeirão Preto, 2003. Resumos. Ribeirão Preto: SBCS, 2003.

ALLOWAY, B.J. Heavy metals in soils. Glasgow: Black and Sons, 1995. 390 p.

ALMEIDA, A.M. de. A resina de troca iônica como extrator multielementar em análise de solos para fins de fertilidade. Campinas, 1999. 103p. Dissertação (Mestrado) Instituto de Química, Universidade Estadual de Campinas. 
AMACHER, M.C. Nickel, cadmium, and lead. In: SPARKS, D.L. ; PAGE, A.L.; HELMKE, P.A.; LOEPPERT, R.H.; SOLTANPOUR, P.N.; TABATABAI, M.A.; JOHNSTON, C.T.; SUMNER, M.E. (Ed.). Methods of soil analysis. Madison: Soil Science Society of America, 1996. pt 3. Chemical methods, p.739-768.

AMARAL SOBRINHO, N.M.B; VELOSO, A.C.X.; COSTA, L.M.; OLIVEIRA, C. Solubilidade de metais pesados em solo tratado com resíduo siderúrgico. Revista Brasileira de Ciência do solo, v.21, p.9-16, 1997.

AREVALO E.F.; STICHNOTHE H.; THOMING J.; CALMANO, W. Evaluation of a leaching process coupled with regeneration/recycling of the extractant for treatment of heavy metal contaminated solids Environmental Science and Technology, v.23, n.5, p.571-581, 2002.

BAKER, D.E. Copper. In: ALLOWAY, B.J. (Ed.). Heavy metals in soils. New York: Halsted, 1993. p.151-176.

BERTONI, J.C.; HOLANDA,F.S.R; CARVALHO, J. G. de; FURTINI NETO, A.E.; ASSIS, M.P. de. Efeito do cobre no crescimento do arroz irrigado por inundação do extrator DTPA na predição da disponibilidade de cobre. Ciência Agrotécnica, v.24, n.1, p.62-73, 2000.

BRAGA, F.G. Cultura da uva niágara rosada. São Paulo: Nobel, 1988. 66p.

BRASIL. Ministério da Agricultura e do Abastecimento. Mapeamento da fruticultura brasileira. Brasília, 2000. 110 p. (EMBRAPA. SPI. Publicação técnica).

BRASIL. Ministério da Agricultura, Pecuária e Abastecimento. <http://oc4j.agricultura.gov.br/agrolegis/Imagem?codArquivo=1675>. (13 set 2004)

BRASIL. Ministério da Agricultura. Secretaria Nacional de Defesa Agropecuária. Análise de corretivos, fertilizantes e inoculantes: métodos oficiais. Brasília, 1988. 104p.

BRUN, L.A.; MAILlET, J.; HINSINGER, P.; PEPIN, M. Relationships between extractable copper, soil properties and copper uptake by wild plants in vineyard soils. Environmental Pollution, v.102, p.151-161, 1998. 
CAMARGO, O.A.; ALLEONI, L.R.F.; CASAGRANDE, J.C. Reações dos micronutrientes e elementos tóxicos. In: FERREIRA, M.E.; CRUZ, M.C.P. da; RAIJ, B.van; ABREU, C.A. de. (Ed.). Micronutrientes e elementos tóxicos na agricultura. Jaboticabal: CNPq; FAPESP; POTAFOS, 2001.cap.5, p.89-124.

CAMARGO, O.A.; MONIZ, A.C.; JORGE, J.A.; VALADARES, J.M.A.S. Método de análise química, mineralógica e física de solos do Instituto Agronômico de Campinas. Campinas: Instituto Agronômico, 1986. 94p. (Boletim Técnico, 106).

CAÑADAS, R.C.; SANCHIDRIAN, J.R; RIVERO, V.V. Distribución de Pd, Cd, Cu y Cr entre distintas fases sólidas en algunos tipos de suelos. Anales de Edafología y Agrobiologia, v.45, p.613-630, 1986.

CANDELARIA, L.M; CHANG, A.C. Cadmium activities, solution speciation, and solid phase distribution of $\mathrm{Cd}$ in cadmium nitrate in sewage sludge-treated soil systems. Soil Science, v.162, n.10, p.722-732,1997.

CATANI, R.A.; BERGAMIN FILHO, H. Sobre uma modificação no método de Neubauer. Anais da Escola Superior de Agricultura Luiz de Queiroz, v.18, p.287-299, 1961.

CERRI, C.C.; POLO, A.; ANDREAUX, F.; LOBO, M.C.; EDUARDO, B.P. Resíduos orgânicos da agroindústria canavieira: 1. Características físicas e químicas. STAB. Açúcar, Álcool e Subprodutos, v.6, n.3, p.34-37, 1988.

CHEN, S.C.; LI, K. H.; FANG, H. Y. Growth kinetics of EDTA biodegradation by Burkholderia cepacia. World Journal of Microbiology and Biotechnology, v.21, n.1, p.11-16, 2005

COLOZZI FILHO, A.; BALOTA, E.L.; CHAVES, J.C.; ANDRADE, D.S. Alterações na biomassa microbiana do solo e em alguns de seus compostos, em função da adubação verde do cafeeiro. In: SIMPÓSIO DE PESQUISA DOS CAFÉS DO BRASIL. 1., Poços de Caldas, 2000. Brasília: Embrapa café e MINASPLAN, 2000. p.1393-1395.

CORDENADORIA DE ASSISTÊNCIA TÉCNICA INTEGRAL. $<$ http://www.cati.sp.gov.brnoticias/m_saiunaimprensa_valinhosmantemsafrafigo.htm l>. (11 dez. 2003). 
CORDENADORIA DE ASSISTÊNCIA TÉCNICA INTEGRAL. $<$ http://www.cati.sp.gov.br>. (28 jan 2005).

DELUISA, A.; GIANDON, P.; AICHNER, M.; BORTOLAMI, P.; BRUNA, L.; LUPETTI, A.; NARDELLI, F.; STRINGARI, G. Copper pollution in italian vineyard soils. Communications in Soil Science and Plant Analysis, v.27, n.5/8, p.1537-1548, 1996.

DERAM, A.; PETIT, D.; ROBINSON, B.; BROOKS, R.; GREGG, P.; HALLUWYN, C.V. Natural and induced heavy-metal accumulation by Arrhenatherum elatius: implications for phytoremediation. Communications in Soil Science and Plant Analysis, v.31, p.413-421, 2000.

EPSTEIN, L.; BASSEIN, S. Pesticide applications of copper on perennial crops in California, 1993 to 1998. Journal of Environmental Quality, v.30, p.1844-1847, 2001.

FLORESTASITE. Calda bordalesa. <http://www.florestasite.com.br/caldabordal.htm>. (10 ago 2003).

FLORES-VÉLEZ, L.M.; DUCAROIR,J.; JAUNET, A.M.; ROBERT, M. Study of the distribution of copper in an acid sandy vineyard soil by three different methods. European. Journal of Soil Science, v.47, n.1, p.523-532, 1996.

GAO, Y.Z.; HE, J.Z.; LING, W.T.; HU, H.Q.; LIU, F. Effects of organic acids on copper and cadmium desorption from contaminated soils. Environment International, v.29, n.5, p.613-618, 2003.

GARCIA, A.W.R.; MARTINS, M.; SALGADO, A.R.; FREIRE, A.C.F. Efeito da adubação química isoladamente, bem como a sua associação com adubos orgânicos na produção do cafeeiro Mundo Novo. In: CONGRESSO BRASILEIRO DE PESQUISAS CAFEEIRAS, 10, Poços de Caldas, 1983. Anais. Poços de Caldas: MIC/IBC, 1983. p. 282-284.

GARDNER, W.K.; BARBER, D.A.; PARBEY, D.G. The acquisition of phosphorus by Lupinus albus L. III. The probable mechanism by which phosphorus movement in the soil.root interface is enhanced. Plant and Soil, v.70, p.107-124, 1983. 
GHILARDI, A. A.; MAIA, M. L. Tecnologia, custo de produção e rentabilidade do cultivo de uva Niágara no Estado de São Paulo. Informações Econômicas, v.31, n.12, p. 48-64, 2001.

GHINI, R. Resistência de fungos a fungicidas. <http://www.radiobras.gov.br/ct/artigos/2001/artigo_280901.htm>. (15 dez 2004).

GIMENEZ, S.M.N.; YABE, M.J.S.; LUNARDELLI, T.B. Interação do cobre com diferentes insumos agrícolas. In: REUNIÃO ANUAL DA SOCIEDADE BRASILEIRA DE QUÍMICA, 22., Poços de Caldas, 1999. Resumos. Poços de Caldas: SBQ, 1999. p.69.

GLÓRIA, N.A. Uso agronômico de resíduos. In: REUNIÃO BRASILEIRA DE FERTILIDADE DO SOLO E NUTRIÇÃO DE PLANTAS, 20., Piracicaba, 1992. Anais. Piracicaba: ESALQ, 1992. p.195-312.

GR`CMAN, H.; VELIKONJA-BOLTA, `S.; VODNIK, D.; KOS, B.; D. LE`STAN, D. EDTA enhanced heavy metal phytoextraction: metal accumulation, leaching and toxicity. Plant and Soil, 235, p.105-114, 2001.

GRZEBISZ, W.; OERTLI, J.J. Evaluation of universal extractants for determining plantavailable potassium in intensively cultivated soils. Communications in Soil Science and Plant Analysis, v. 24, n.11/12, p.1295-1308, 1993.

GUIHERME, L.R.G.; ANDERSON, S.J. Copper sorption kinetics and sorption hysteris in tow oxide-rich soils (Oxisols). In VENNE, E.A. (Ed). Adsorption of metals by geomedia: variables, mechanisms and model aplications. San Diego: Academic Press, 1998. cap.9, p.209-228.

GUTIERREZ, A.S.D. 0 negócio de frutas frescas. $<$ http://www.iea.sp.gov.br/out/verTexto.php?codTexto=563>. (15 jun 2004).

HARRIS, D.C. Quantitative chemical analysis. New York: W.H. Freeman, 1995. 837 p.

HOODA, P.S.; ALLOWAY, B.J. The effect of liming on heavy metal concentrations in wheat, carrots and spinach grown on previously sludge applied soils. Journal of Agricultural Science, v.127, p.289-294, 1996.

INSTITUTO BRASILEIRO DE GEOGRAFIA E ESTATÍSTICA. Produção agrícola municipal: culturas temporárias e permanentes. Rio de Janeiro, 2003. v.30, p.1-93, 2003. 
JONES, D.L.; DARRAH, P.R.; KOCHIAN, L.V. Critical evaluation of organic acid mediated iron dissolution in the rizosphere and its potential role in root ion uptake. Plant and Soil, v.182, p.221-228, 1996.

KABALA, C.; SINGH, B.R. Fractionation and mobility of copper, lead, and zinc in soil profiles in the vicinity of a copper smelter. Journal of Environmental Quality, v.30, p.485-492, 2001.

KARCZEWSKA, A. Chemical speciation and fate of selected heavy metals in soils strongly polluted by copper smelters. In: REUTHER, R. (Ed.). Geochemical approaches to environmental engineering of metals, New York: Springer, 1996, p. 55-79.

LAKE, D.L.; KIRK, P.W.W.; LESTER, J.N. Fractionation, characterization and speciation of heavy metal in sewage sludge and sludge amended soils, a review. Journal of Environmental Quality, v.13, p.175-183, 1984.

LI, M.G.; SHIANANO, T.; TADANO, T. Distribution of exudates of lupin roots in the rhizosphere under phosphorus deficient conditions. Soil Science and Plant Nutrition, v.43, p. 137-245, 1997.

LI, R.N. Effect of long-term applications of copper on soil and grape copper (Vitisvinifera). Canadian Journal of Soil Science, v.74, n.3, p.345-347, 1994

LOPES, A.S.; CARVALHO, J.G. de. Micronutrientes: critérios de diagnose para solo e planta. In: SIMPÓSIO SOBRE ENXOFRE E MICRONUTRIENTES NA AGRICULTURA BRASILEIRA, Londrina, 1988. Anais. Londrina: EMBRAPA CNPSo. IAPAR; SBCS, 1988. p. 133-178.

MACNICOL, R.D.; BECKETT, P.H.T. Critical tissue concentrations of potentially toxic elements. Plant and Soil, v.85, p.107-129, 1985.

MAIORANO, J.A. Importância econômica da figueira no estado de São Paulo. In: SIMPÓSIO BRASILEIRO SOBREA CULTURA DA FIGUEIRA, 1., Ilha Solteira, 1999. Anais. São Paulo: FUNEP, 1999. p. 22

MALAVOLTA, E. Fertilizantes e seu impacto ambiental: metais pesados, mitos, mistificação e fatos. São Paulo: Produquímica, 1994. 153p. 
MANTOVANI, J.R; CRUZ, M.C.P; FERREIRA, M.E; ALVES, W.L. Extratores para avaliação da disponibilidade de metais pesados em solos adubados com vermicomposto de lixo urbano. Pesquisa Agropecuária Brasileira, v.39, n.4, p.371-378, 2004.

MARCHIORI JUNIOR, M. Impacto ambiental da citricultura nos teores de metais pesados em solos do Estado de São Paulo. Jaboticabal, 2002. 83p. Tese (Doutorado) Faculdade de Ciências Agrárias e Veterinárias, Universidade Estadual Paulista “Júlio Mesquita Filho".

MARSCHNER, H. Mineral nutrition of higher plants. London: Academic Press, 1995. 889 p.

MATERECHERA, S.A. Neubauer seedling technique to determine availability of nutrient elements for wheat from selected South African soils. Communications in Soil Science and Plant Analysis, v.30, n.19-20, p.2755-2767, 1999.

MCBRIDE, M.B. Reactions controlling heavy metal solubility in soils. Advances in Soil Science, v.10, p.1-47, 1989.

MCLAUGHLIN, M.J.; HAMON, R.E.; MCLAREN, R.G.; SPEIR, T.W.; ROGERS, S.L. Review: a bioavailability-based rationale for controlling metal and metalloid contamination of agricultural land in Australia and New Zealand. Australian Journal of Soil Research, v.38, 1037-1086, 2000.

MELLO, F.A.F. de; BRASIL SOBRINHO, M.O.C.; ARZOLLA, S.; SILVEIRA, R.I.; COBRA NETTO, A.; KIEHL, J.C. Fertilidade do solo. São Paulo: Nobel, 1983. 400 p.

MICHEREFF, S.J. Controle químico de doenças de plantas. <http://www.ufrpe.br:6789/fitopatologia/teoricas/T19.pdf> (06 jul 2004).

MIYAZAWA M.; GIMINEZ, S.M.N.; YABE, M.J.S; OLIVEIRA, E.L.; KAMOGAWA, M.Y. Absorption and toxicity of copper and zinc in bean plants cultivated in soil treated with chicken manure. Water, Air, and Soil Pollution v.138, n.1/4, p.211-222, 2002.

MOLINARI, R.; POERIO, T.; ARGURIO, P. Polymer assisted ultrafiltration for copper-citric acid chelate removal from wash solutions of contaminated soil. Journal of Applied Electrochemistry, v.35, p.375-380, 2005. 
MURAYAMA, S. Fruticultura. 2.ed. Campinas: Instituto Campineiro de Ensino Agrícola, 1980. 385p.

NOGUEIROL, R.C.; NACHTIGALL, G.R.; LOPES, C.M.; CAMBRI, M.A.; ALLEONI, L.R.F. Avaliação de extratores de cobre em solos de vinhedo. In: SIMPÓSIO INTERNACIONAL DE INICIAÇÃO CIENTIFICA DA UNIVERSIDADE DE SÃO PAULO, 11.; REUNIÃO PAULISTA DE INICIAÇÃO CIENTIFICA EM CIÊNCIAS AGRÁRIAS, 14.; CONGRESSO DE INICIAÇÃO CIENTIFICA DA ESALQ, Piracicaba, 2003. Resumos. São Paulo: USP, 2003. p.14. NOGUEIROL, R.C.; NACHTIGALL, G.R.; LOPES, C.M.; CAMBRI, M.A.; ALLEONI, L.R.F. Copper and zinc in the organic fraction of vineyard soils as a function of $\mathrm{pH}$ variation. In: INTERNATIONAL MEETING OF THE INTERNATIONAL HUMIC SUBSTANCES SOCIETY, 12, São Pedro, 2004. Proceedings. São Carlos: EMBRAPA/Instrumentação Agropecúaria, 2004. p.707-709.

NOLAN, A. L.; MCLAUGHLIN, M.J.; MASON, S.D. Chemical speciation of Zn, Cd, $\mathrm{Cu}$, and $\mathrm{Pb}$ in pore waters of agricultural and contamined soils using Donann dialysis Environmental Science \& Technology, v.37, n.1, p.90-98, 2003

PARAT, C.; CHAUSSOD, R.; LEVEQUE, J.; DOUSSET, S.; ANDREUX, F. The relationship between copper accumulated in vineyard calcareous soils and soil organic matter and iron. European Journal of Soil Science, v.53, n.4, p. 663-669, 2002.

PENTEADO, S.R. Controle alternativo de pragas e doenças com as caldas bordalesa sulfocálcica e viçosa. Campinas: Bueno Mendes Gráfica e Editora, 2000. 89p.

PENTEADO, S.R. Defensivos alternativos e naturais: para uma agricultura saudável. Campinas: S.R. Penteado, 1999. 79p.

PEREZ, L.H.; ROCHA, M.B.; MAZZEI, A.R.; ALVES, H.S. Análise da comercialização do Figo em São Paulo, 1990-2001. Informações Econômicas, v.33, n.6, jun, 2003. $<$ http://www.iea.sp.gov.br/out/verTexto.php?codTexto=780>. (12 dez 2003). 
PIERRISNARD, F. Intact de I'amendment dês boues residuaires de la ville de Marseille sur de sols a vocatio acgicole: comportament du $\mathrm{Cd}, \mathrm{Cr}, \mathrm{Cu}, \mathrm{Ni}, \mathrm{Pb}$ e $\mathrm{Zn}$ des hidrocarures et des composes polares. Marseille, 1996. 408 p. These - (Docteur Géosciences de I’Emvironnement) - Université de Droit d'Economie et dês Science d'AIX-MARSEILLE.

POMMER, C.V.; PASSOS, I.R.S.; TERRA, M.M.; PIRES, E.J.P. Variedades de videira para o Estado de São Paulo. Campinas: Instituto Agronômico, 1997. 59 p. (Boletim Técnico, 166).

RAIJ, B. van. New diagnostic techniques, universal soil extractants. Communications in Soil Science and Plant Analysis, v.25, p.799-816, 1994.

RAIJ, B.van. Fertilidade do solo e adubação. São Paulo: Ceres; Piracicaba: Potafos, 1991. 343p.

RAIJ, B.van; QUAGGIO, J.A.; CANTARELLA, H.; ABREU, C.A. Interpretação dos resultados de análise de solo. In: RAIJ, B.van; CANTARELLA, H.; QUAGGIO, J.A.; FURLANI, A.C. (Ed.). Recomendações de adubação e calagem para o estado de São Paulo. 2.ed. Campinas: Instituto Agronômico; Fundação IAC, 1996. p.8-13. (Boletim Técnico, 100).

RAMALHO, J.F.G. Metais pesados em solos com diferentes usos agrícolas no estado do Rio de Janeiro. Seropédica, 1996. 160 p. Tese (Doutorado) Universidade Federal Rural do Rio de Janeiro.

RAMALHO, J.F.G.P.; AMARAL SOBRINHO, N.M.B. Metais pesados em solos cultivados com cana-de-açúcar pelo uso de resíduos agroindustriais. Floresta e Ambiente, v.8, n.1, p.120-129, 2001.

REVISTA GLOBO RURAL. Exportação de frutas chegam a US\$ 370 milhões em 2004. <http://revistagloborural.globo.com>. (01 mar 2005).

RODELLA, A.A. Nutrient response relationships between ratoon and plant crops in sugarcane. Sugar Cane, n.1, p.3-7, 1990.

RODELLA, A.A.; ALCARDE, J.C. Avaliação de materiais orgânicos empregados como fertilizantes. Scientia Agrícola, v.51, n.32, p.556-562, 1994. 
RODELLA, A.A.; FISCHER, K.R.; ALCARDE, J.C. Cation exchande capacity of an acid soil as influenced by different sources of organic litter. Communications in Soil Science and Plant Analysis, v.26, n.17/18, p.2961-2967, 1995.

RODELLA, A.A.; LAVORENTI, A.; MATTIAZZO-PREZOTTO, M.E. Guia de aulas teóricas e exercícios: disciplinas: LCE-108 - química inorgânica e analítica, LCE118 - química geral, LCE-151 - fundamentos de química inorgânica e analítica. Piracicaba: ESALQ, 2003. 120 p.

RODELLA, A.A.; SILVA, L.C.F. da; ORLANDO FILHO, J. Effects of filter cake application on sugarcane yields. Turrialba, v.40, n.3, p.323-326, 1990.

ROSS, S.M. Retention, transformation and mobility of toxic metals in soils. In: ROSS, S.M. (Ed.). Toxic metals in soil-plant systems, New York: Wiley, 1994. p.63-152.

RUPA, T.R.; SHUKLA, L.M. Comparison of four extractants and chemical fractions for assessing available zinc and copper in soils of India. Communications in Soil Science and Plant Analysis, v.30, n.19/20, p.2579-2591, 1999.

SPOSITO, G.; LUND, L.J.; CHANG, A.C.; Trace metal chemistry in arid-zone field soil amended with sewage sludge: I. Fractionation of $\mathrm{Ni}, \mathrm{Cu}, \mathrm{Zn}, \mathrm{Cd}$ and $\mathrm{Pb}$ in solid phases. Soil Science Society of America Journal, v.46, p.260-264, 1982.

TAWINTEUNG N.; PARKPIAN P.; DELAUNE R.D.; JUQSUJINDA, A. Evaluation of extraction procedures for removing lead from contaminated soil. Journal of Environmental Science and Health, v.40, n.2, p.385-407, 2005.

TESSIER, A.; CAMPBELL, P.G.C. Portioning of trace metals in sediments. In: KRAMER, J.R. AND ALLEN, H.E. (Ed.). Metal speciation: theory, analysis and application. Chelsea: Lewis Publishers,1988. p.183-199.

TESSIER, A.; CAMPBEL, P.G.C.; BISSON, M. Sequential extraction procedure for the speciation of particulate trace metals. Analytical Chemistry, v.51, p.844-851, 1979.

THAYALAKUMARAN, T.; ROBINSON, B.H.; VOGELER, I.; SCOTTER, D.R.; CLOTHIER, B.E.; PERCIVAL, H.J. Plant uptake and leaching of copper during EDTA-enhanced phytoremediation of repacked and undisturbed soil. Plant and Soil, v.254, p.415-423, 2003. 
TIFFIN, L.O. The form and distribution of metals in plants: an overview. In: ANNUAL HANFORD LIFE SCIENCES SYMPOSIUM AT RICHLAND, 15., Washington, 1975. Washingthon: Technical Information Center, 1977. p.315-334.

UNITED STATES. Environmental Protection Agency. Method 3050: acid digestion of sediments, sludges and soils.<http://www.epa.gov/SW-846/pdfs/3050b.pdf>. (20 out 2003).

VALE, F. Avaliação e caracterização da disponibilidade do boro e zinco contidos em fertilizantes. Piracicaba, 2000. Tese (Doutorado) - Escola Superior de Agricultura “Luiz de Queiroz”, Universidade de São Paulo.

VALE, F.; ALCARDE, J.C. Solubilidade e disponibilidade dos micronutrientes em fertilizantes. Revista Brasileira de Ciência do Solo, v.23, p.441-451, 1999.

VANDERWATT, H.V.; SUMNER M.E.; CABRERA, M.L. Bioavailability ff copper, manganese, and zZinc in poultry litter. Journal of Environmental Quality, v.23, n.1, p.43-49, 1994

VASSIL, A.D.; KAPULNIK, Y.; RASKIN, I.; SALT, D.E. The role of EDTA in lead transport and accumulation by Indian Mustard. Plant Physiology, v.117, n.2, p.447453, 1998.

VIETS JUNIOR, F.G. Chemical end availability of heavy metal in soils. Journal of Agriculture and Food Chemistry, v.10, p.174-178, 1962.

VULKAN, R.; ZHAO, F.J.; BARBOSA-JEFFERSON, V.; PRESTON, S.; PATON, G.I.; TIPPING, E.; MCGRATH, S.P. Copper speciation and impacts on bacterial biosensors in the pore water of copper-contaminated soils. Environmental Science and Technology, v.34 n.24, p.5115-5121, 2000.

WAGEMANN, R. Cupric ion-selective electrode and inorganic cationic complexes of copper, Journal of Physical Chemistry, v. 84, n.25, p.3433-3436, 1980

WALKLEY, A.; BLACK, I.A. An examination of the Degtjareff method for determining soil organic matter, and a proposed modification of the chromic acid titration method. Soil Science, v.37, p.29-38, 1934. 
WU, L.H.; LUO, Y.M.; XING, X.R.; CHRISTIE, P. EDTA-enhanced phytoremediation of heavy metal contaminated soil with Indian mustard and associated potential leaching risk Agriculture Ecosystems \& Environment, v.102, n.3, p.307-318, 2004.

YU, P.F.; JUANG, K.W.; LEE, D.Y. Assessment of the phytotoxicity of chromium in soils using the selective ion exchange resin extraction method. Plant and Soil, v.258, n.1, p.333-340, 2004.

ZONTA, E.P.; MACHADO, A.A. SANEST: sistema de análise estatística para microcomputadores. Piracicaba: CIAGRI/ESALQ, 1993. 138p. 